\title{
Coumarin Derivatives as Substrate Probes of Mammalian Cytochromes P450 2B4 and 2B6: Assessing the Importance of 7- Alkoxy Chain Length, Halogen Substitution, and Non-Active Site Mutations
}

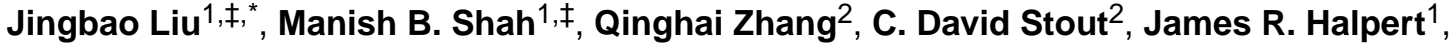 \\ and P. Ross Wilderman ${ }^{1}$ \\ ${ }^{1}$ School of Pharmacy, University of Connecticut, Storrs, CT 06269, United States \\ ${ }^{2}$ Department of Molecular Biology, The Scripps Research Institute, La Jolla, CA 92037, United \\ States
}

\begin{abstract}
Using a combined structural and biochemical approach, the functional importance of a recently described peripheral pocket bounded by the E-, F-, G-, and I-helices in CYP2B4 and 2B6 was probed. Three series of 4-substituted-7-alkoxycoumarin derivatives with a $-\mathrm{H},-\mathrm{CH}_{3}$, or $-\mathrm{CF}_{3}$ at the 4 position of the coumarin core were used initially to monitor functional differences between CYP2B4 and 2B6. 7-Ethoxy-4-(trifluoromethyl)coumarin (7-EFC) displayed the highest catalytic efficiency among these substrates. Mutants were made to alter side-chain polarity (V/E194Q) or bulk (F/Y244W) to alter access to the peripheral pocket. Modest increases in catalytic efficiency of 7-EFC $O$-deethylation by the mutants were magnified considerably by chlorination or bromination of the substrate ethoxy chain. A structure of CYP2B6 Y244W in complex with (+)-a-pinene was solved at $2.2 \AA$ and showed no CYMAL-5 in the peripheral pocket. A ligand free structure of CYP2B4 F244W was solved at $3.0 \AA$ with CYMAL-5 in the peripheral pocket. In both instances, comparison of the respective wild-type and mutant CYP2B enzymes revealed that CYMAL-5 occupancy of the peripheral pocket had little effect on the topology of active site residue sidechains, despite the fact that the peripheral pocket and active site are located on opposite sides of
\end{abstract}

\footnotetext{
"Corresponding Author: Jingbao Liu, University of Connecticut, School of Pharmacy, Department of Pharmaceutical Sciences, 69 North Eagleville Road, Unit 3092, Storrs, CT 06269-3092. jingbao.liu@uconn.edu; Tel: 860-486-3103;.

*These authors contributed equally to this work and should be considered co-first authors.

Supplementary Material: The supplementary material includes a table of the primers used for site directed mutagenesis, a table of crystallographic refinement information, a protocol for spectral binding titrations used for measuring the interaction of $(+)$ - $a$-pinene with CYP2B6 Y244W, and 1H-NMR and 13C-NMR spectra of synthesized compounds described in this manuscript. This material is available free of charge via the Internet at http://pubs.acs.org.

Author Contributions: Participated in research design: Liu and Halpert.

Conducted experiments: Liu.

Contributed new reagents: Zhang.

Performed data analysis: Liu, Shah, Halpert, and Wilderman.

Wrote or contributed to the writing of the manuscript: Liu, Shah, Stout, Halpert, and Wilderman.

${ }^{1}$ In this manuscript, CYP2B4 wild-type will refer to CYP2B4dH H226Y and CYP2B6 wild-type will refer to CYP2B6dH Y226H/ K262R unless otherwise indicated. These are an N-terminally truncated and modified and C-terminally His-tagged forms of CYP2B4dH and CYP2B6dH, respectively.

${ }^{2}$ Accession Codes: Atomic coordinates and structure factors for the P450 2B4 F244W ligand free and 2B6 Y244W-(+)-a-pinene complexes are deposited in the Protein Data Bank as entries 5EM4 and 4ZV8, respectively.
} 
the I-helix. Analysis of available CYP2B structures suggest that the effect of the amino acid substitutions within the peripheral pocket derive from altered interactions between the $F$ and $G$ helices.

\section{Graphical abstract}

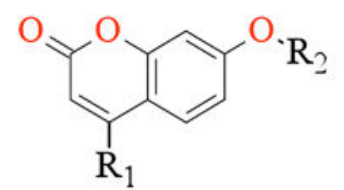

$\mathrm{R}_{1}=-\mathrm{H},-\mathrm{CH}_{3},-\mathrm{CF}_{3}$

$\mathrm{R}_{2}=\mathrm{C}_{2}-\mathrm{C}_{4}$

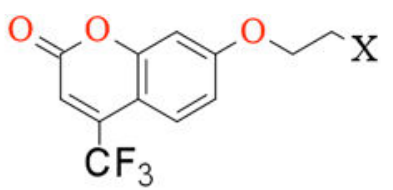

7-BrEFC $\mathrm{X}=\mathrm{Br}$

$7-\mathrm{ClEFC} \mathrm{X}=\mathrm{Cl}$

\section{Keywords}

cytochrome P450; CYMAL-5; coumarin derivatives; (+)-a-pinene; $O$-dealkylation; X-ray diffraction

The metabolism and clearance of drugs and xenobiotic compounds depends heavily on members of the cytochrome P450 (CYP) superfamily (1). In humans, these enzymes are the main route for phase I metabolism of drugs (2). However, the conformational diversity and plasticity of the active sites of drug-metabolizing CYP enzymes can limit the predictive value of one structure of a CYP ligand complex for binding of other ligands $(3,4)$. To better understand metabolism mediated by CYP enzymes, the specific interaction between the substrate and residues within as well as outside the active site must be taken into account (1, 2).

Xenobiotic metabolizing CYP enzymes utilize a primarily alpha helical single domain protein fold to accept a broad range of substrates $(5,6)$. Substrates oxidized by members of the CYP2B subfamily of enzymes are generally non-planar lipophilic molecules that may be neutral or weakly basic and possess one or two hydrogen-bond acceptors (7-9). Members of this subfamily of enzymes were among the first mammalian CYP enzymes to be purified and cloned, and the low preservation of CYP2B catalytic activities across mammalian species makes this subfamily a good platform for CYP enzyme structure-function studies $(10,11)$. A substantial body of biochemical and biophysical information regarding CYP2B protein-ligand and protein-protein interactions and the catalytic mechanisms of microsomal monooxygenases is available (10-12). Techniques including site-directed mutagenesis, isothermal titration calorimetry, high-pressure spectroscopy, and hydrogen/deuterium exchange coupled to mass spectrometry have been used to probe the functional and solution structural behavior of CYP2B enzymes (10-13). Furthermore, X-ray crystallography has revealed that CYP2B enzymes adopt multiple conformations to facilitate binding of substrates with a wide range of molecular weights $\left(\mathrm{M}_{\mathrm{r}}=\sim 75-800\right)(10,11,14,15)$.

The representative of the CYP2B subfamily found in humans, CYP2B6, takes part in the metabolism of 3 to $12 \%$ of all drugs (16), and a number of single nucleotide polymorphisms are known, all of which occur outside the enzyme active site $(17,18)$. Some of these amino 
acid differences lead to altered binding or metabolism of clinically relevant drugs $(9,18)$. Furthermore, alteration of select non-active site residues in CYP2B enzymes indicated that these changes distal from the enzyme active site can significantly affect protein stability, ligand binding and/or catalysis $(19,20)$.

CYP2B6 also displays non-Michaelis-Menten kinetics with some substrates (21). Nonhyperbolic kinetics in CYP enzymes has been most heavily studied in human CYP3A4; explanations for this phenomenon include enzyme conformational heterogeneity, binding of multiple ligand molecules in the enzyme active site, or the presence of a peripheral binding site $(22,23)$. CYP3A4 was initially crystallized with progesterone bound at a peripheral site, and a recent report utilizing isomeric testosterone dimers found that binding of a monomeric testosterone molecule to a distal allosteric site enhanced binding when the trans-testosterone dimer occupied the enzyme active site $(24,25)$. In CYP2B enzymes, a peripheral pocket was recently described that is bounded by the E-, F-, G-, and I-helices and is occasionally occupied by 5-cyclohexyl-1-pentyl- $\beta$-d-maltoside (CYMAL-5) in X-ray crystal structures (26). This cavity is physically separated from the active site of CYP2B enzymes by the Ihelix (Figure 1). Previously observed rearrangements of the I-helix likely allow for optimal ligand interaction with the heme group (27). Site-directed mutagenesis of residues within or near the surface of this peripheral pocket revealed that CYP2B4 F202W and CYP2B6 F202W had little or no catalytic activity with the model substrate 7-ethoxy-4(trifluoromethyl)coumarin (7-EFC), primarily due to enhanced uncoupling to excess water, whereas CYP2B4 F195W showed no change in 7-EFC $O$-deethylation activity (26).

Alkoxycoumarin derivatives are model substrates of CYP enzymes due to their general hydrophobicity and the production of fluorescent products. Previous studies have shown that the length of the alkoxy chain is an important determinant of $O$-dealkylation of 7-substituted coumarins by CYP2B1 and CYP3A4 and a number of active site mutants (28-31). In the present study, the active sites of CYP2B4 and CYP2B6 were probed using three series of 4substituted-7-alkoxycoumarins as substrates to assess the importance of substituents with different electronic properties $\left(-\mathrm{H},-\mathrm{CH}_{3},-\mathrm{CF}_{3}\right)$ at the 4 position of the coumarin core along with varied length $(\mathrm{C} 2-\mathrm{C} 4)$ and/or halogen substitution $(-\mathrm{Cl},-\mathrm{Br})$ of the alkoxy chain at the 7 position. In parallel using site-directed mutagenesis, residues on the surface of CYP2B4 or CYP2B6 were mutated to alter side-chain polarity (V/E194Q) or bulk (F/Y244W) in an effort to block detergent access to the peripheral pocket and assess the effect of CYMAL-5 binding on active site topology. For this purpose, X-ray crystal structures of CYP2B4 F244W in the absence of ligand and CYP2B6 Y244W in the presence of the monoterpene (+)-a-pinene were solved. The functional consequences of these mutations were assessed using 7-EFC and its two halogenated derivatives.

\section{Materials and Methods}

\section{Materials}

7-ethoxycoumarin (7-EC), 7-propoxycoumarin (7-PrC) and 7-butoxycoumarin (7-BuC) were synthesized by Dr. E. Mash (Department of Chemistry, The University of Arizona). 7hydroxy-4-(trifluoromethyl)coumarin (7-HFC) was purchased from Alfa Aesar. 7hydroxycoumarin (7-HC), 7-hydroxy-4-methylcoumarin (7-HMC) and 7-ethoxy-4- 
(trifluoromethyl)coumarin (7-EFC) were purchased from Invitrogen (Carlsbad, CA). ${ }^{1} \mathrm{H}$ and ${ }^{13} \mathrm{C}$ NMR spectrum were recorded on a Bruker AVANCE $500 \mathrm{MHz}$ spectrometer using TMS as an internal standard (chemical shifts in $\delta$ ), and analysis was done using MestReNova version 8.0.0. Peak multiplicities of NMR signals were designated as $\mathrm{s}$ (singlet), d (doublet), dd (doublet of doublet), t (triplet), m (multiplet). HRMS was performed at the University of Connecticut Mass Spectrometry Facility by Dr. You-Jun Fu, on a JEOL AccuTOF (Peabody, MA) mass spectrometer using a DART (IonSense) ionization source. All chemical structures were created using Accelrys Draw 4.1. $\beta$-NADPH, ribonuclease A (RNase A), and deoxyribonuclease I (DNase I) were purchased from SigmaAldrich (St. Louis, MO). Nickel-nitrilotriacetic acid $\left(\mathrm{Ni}^{2+}{ }_{-} \mathrm{NTA}\right)$ affinity resin was from ThermoFisher Scientific (Waltham, MA), and Macro-Prep CM cation exchange resin was obtained from Bio-Rad Laboratories (Hercules, CA). Amicon Ultra and Ultrafree-MC centrifugal filter units were purchased from Millipore (Billerica, MA). The QuikChange XL site-directed mutagenesis kit and Escherichia coli (E. coli) TOPP3 and JM109 cells were obtained from Agilent (Santa Clara, CA). The molecular chaperone plasmid pGro7 was obtained from Takara Bio (Shiba, Japan). Recombinant NADPH cytochrome P450 reductase (CPR) and cytochrome $b_{5}$ from rat liver were prepared as described previously $(32,33)$. Primers were synthesized by Integrated DNA Technologies (Coralville, IA). Crystal Screen 2 was obtained from Hampton Research (Aliso Viejo, CA), and the Wizard 3 crystal screen was obtained from Rigaku (The Woodlands, TX). 3a-, 7a-, 12a-Tris[( $\beta$-Dmaltopyranosyl)ethyloxy] cholane (FA-4) is a custom made facial amphiphile (34). All other chemicals and supplies were obtained from standard commercial sources and are of the highest purity available.

\section{Site-Directed Mutagenesis}

CYP2B4 mutants were created using the pKK2B4dH (H226Y) plasmid as a template (35), and CYP2B6 mutants were created using the pKK2B6dH (Y226H/K262R) plasmid as a template (14). Mutants were created by polymerase chain reaction (PCR) with the QuikChange XL site-directed mutagenesis kit from Agilent and a standard site-directed mutagenesis protocol. Forward and reverse primers used for site-directed mutagenesis are shown in Table S1. All constructs were sequenced at Retrogen Inc. (San Diego, CA, USA) to verify the intended mutations were present and the absence of extraneous mutations.

\section{Protein Expression and Purification}

CYP2B4 enzymes were expressed in E. coli TOPP3 cells; CYP2B6 proteins were coexpressed with the GroEL/ES chaperones (pGro7 plasmid) in E. coli JM109 cells, as described previously $(15,36)$. In brief, protein expression was carried out for $72 \mathrm{hrs}$ at $30{ }^{\circ} \mathrm{C}$ after induction with isopropyl $\beta$-D-1-thiogalactopyranoside $(1 \mathrm{mM})$ and supplementing the culture with $\delta$-aminolevulinic acid $\left(0.5 \mathrm{mM}, A_{600} \sim 0.7\right.$ at $\left.37^{\circ} \mathrm{C}\right)$ in the presence of ampicillin (100 $\mu \mathrm{g} / \mathrm{ml}$, CYP2B4 enzymes) or L-(+)-Arabinose $(20 \mathrm{mg} / \mathrm{ml})$, ampicillin and chloramphenicol ( $25 \mu \mathrm{g} / \mathrm{ml}$, CYP2B6 enzymes). The cells were harvested by centrifugation $(4,000 \times g, 10 \mathrm{~min})$. The cell pellets were resuspended in $10 \%$ of the original culture volume in buffer containing $20 \mathrm{mM}$ potassium phosphate (pH 7.4 at $\left.4{ }^{\circ} \mathrm{C}\right), 20 \%$ (v/v) glycerol, 10 $\mathrm{mM}$ BME, and $0.5 \mathrm{mM}$ PMSF. The resuspended cells were treated with lysozyme $(0.3$ $\mathrm{mg} / \mathrm{mL}$ ) and stirred for $30 \mathrm{~min}$ at $4{ }^{\circ} \mathrm{C}$, and then followed by centrifugation for $30 \mathrm{~min}$ at 
$7500 \times g$ in a JA-14 rotor in a Beckman Coulter Avanti J-26 XPI Centrifuge. After decanting the supernatant, the spheroplasts were resuspended in $5 \%$ of the original volume in the buffer containing $500 \mathrm{mM}$ potassium phosphate (pH 7.4 at $\left.4{ }^{\circ} \mathrm{C}\right), 20 \%(\mathrm{v} / \mathrm{v})$ glycerol, 10 $\mathrm{mM}$ BME, $0.5 \mathrm{mM}$ PMSF, $10 \mu \mathrm{g} / \mathrm{mL}$ RNase A, and $10 \mu \mathrm{g} / \mathrm{mL}$ DNase I. The resulting suspension was then sonicated $4 \times 1 \mathrm{~min}$ on ice. The lysate was stirred for $90 \mathrm{~min}$ at $4{ }^{\circ} \mathrm{C}$ in the presence of CHAPS at a final concentration of $0.8 \%(\mathrm{w} / \mathrm{v})$. After ultracentrifugation for $1 \mathrm{~h}$ at 245,000×g using a fixed-angle Ti 50.2 rotor in an Optima L-80 XP Ultracentrifuge, the supernatant was collected and the concentration was measured using the reduced $\mathrm{CO}$ difference spectra (37).

The supernatant was applied to a $\mathrm{Ni}^{2+}$-NTA column and washed with buffer containing 100 $\mathrm{mM}$ potassium phosphate $\left(\mathrm{pH} 7.4\right.$ at $4{ }^{\circ} \mathrm{C}$ ), $100 \mathrm{mM} \mathrm{NaCl}, 20 \%$ (v/v) glycerol, $10 \mathrm{mM}$ BME, $0.5 \mathrm{mM}$ PMSF, $0.5 \%(\mathrm{w} / \mathrm{v})$ CHAPS, and $5 \mathrm{mM}$ histidine. The protein was eluted using $50 \mathrm{mM}$ histidine in the same buffer. The highest purity fractions as measured by the $A_{417} / A_{280}$ ratio were pooled, and the CYP enzyme concentration was measured using the reduced $\mathrm{CO}$ difference spectra. Pooled fractions were diluted with buffer containing $5 \mathrm{mM}$ potassium phosphate ( $\mathrm{pH} 7.4$ at $4{ }^{\circ} \mathrm{C}$ ), $20 \%$ (v/v) glycerol, $1 \mathrm{mM}$ EDTA, $0.2 \mathrm{mM}$ DTT, 0.5 $\mathrm{mM}$ PMSF, and $0.5 \%(\mathrm{w} / \mathrm{v})$ CHAPS and loaded onto an equilibrated Macro-Prep CM cation exchange column. The column was washed using $5 \mathrm{mM}$ potassium phosphate $(\mathrm{pH} 7.4$ at $4{ }^{\circ} \mathrm{C}$ ), $20 \mathrm{mM} \mathrm{NaCl}, 20 \%$ (v/v) glycerol, $1 \mathrm{mM}$ EDTA, and $0.2 \mathrm{mM}$ DTT, and the protein was eluted using $50 \mathrm{mM}$ potassium phosphate (pH 7.4 at $4{ }^{\circ} \mathrm{C}$ ), $500 \mathrm{mM} \mathrm{NaCl}, 20 \%$ (v/v) glycerol, $1 \mathrm{mM}$ EDTA, and $0.2 \mathrm{mM}$ DTT. The fractions containing the highest purity protein as measured by the $A_{417} / A_{280}$ ratio were collected, and the concentration was measured using the reduced $\mathrm{CO}$ difference spectra.

\section{Chemical Synthesis}

All compounds were synthesized in similar manner according to published methods (38, 39), and the purity of the compounds exceeds $95 \%$ by ${ }^{1} \mathrm{H}$ NMR.

7-ethoxy-4-methylcoumarin (7-EMC) - To a solution of 7-hydroxy-4-methyl coumarin (100.00 mg, $0.57 \mathrm{mmol}, 1$ equiv) in $\mathrm{CH}_{3} \mathrm{CN}(5 \mathrm{~mL})$, was added $\mathrm{K}_{2} \mathrm{CO}_{3}(78.70 \mathrm{mg}, 0.57$ mmol, 1 equiv) and $\mathrm{CH}_{3} \mathrm{CH}_{2} \mathrm{Br}$ (123.06 $\mathrm{mg}, 1.14 \mathrm{mmol}, 2$ equiv). The reaction mixture was refluxed at $80^{\circ} \mathrm{C}$ for overnight. The crude mixture was filtered and washed the residue using $\mathrm{CH}_{3} \mathrm{CN}(10 \mathrm{~mL})$. The combined organic layer was dried over $\mathrm{MgSO}_{4}$, and concentrated in vacuo, and then purified with flash chromatography $\left(\mathrm{SiO}_{2}, 5-20 \%\right.$ Ethyl Acetate in nHexanes) to afford 7-ethoxy-4-methylcoumarin as a colorless solid (80 mg, 69\% yield). ${ }^{1} \mathrm{H}$ NMR (500 MHz, $\left.\mathrm{CDCl}_{3}, 25^{\circ} \mathrm{C}\right): \delta$ 7.46-7.48 (d, $\left.1 \mathrm{H}, \mathrm{J}=10 \mathrm{~Hz}\right), 6.83-6.85(\mathrm{~d}, 1 \mathrm{H}, \mathrm{J}=10 \mathrm{~Hz})$, $6.78(\mathrm{~s}, 1 \mathrm{H}), 6.11(\mathrm{~s}, 1 \mathrm{H}), 4.06-4.10$ (q, $2 \mathrm{H}, \mathrm{J}=5 \mathrm{~Hz}, 5 \mathrm{~Hz}), 2.38$ (s, 3H), 1.43-1.46 (t, 3H, $\mathrm{J}=7.5 \mathrm{~Hz}) .{ }^{13} \mathrm{C} \mathrm{NMR}\left(125 \mathrm{MHz}, \mathrm{CDCl}_{3}, 25{ }^{\circ} \mathrm{C}\right): \delta 162.3,161.6,155.6,152.8,125.8,113.7$, 112.9, 112.1, 101.6, 64.4, 18.9, 14.8. DART-HRMS: $\mathrm{m} / \mathrm{z}$ calcd. for $\mathrm{C}_{12} \mathrm{H}_{12} \mathrm{O}_{3}[\mathrm{M}+\mathrm{H}]^{+}$: 205.08; Found: 205.08.

7-propoxy-4-methylcoumarin (7-PrMC)—Colorless solid, $48 \%$ yield. ${ }^{1} \mathrm{H}$ NMR (500 $\left.\mathrm{MHz}, \mathrm{CDCl}_{3}, 25^{\circ} \mathrm{C}\right): \delta$ 7.45-7.46 (d, 1H, J=5 Hz), 6.82-6.83 (d, 1H, J=5 Hz), $6.77(\mathrm{~s}, 1 \mathrm{H})$, $6.09(\mathrm{~s}, 1 \mathrm{H}), 3.94-3.96(\mathrm{t}, 2 \mathrm{H}, \mathrm{J}=5 \mathrm{~Hz}), 2.37(\mathrm{~s}, 3 \mathrm{H}), 1.80-1.84(\mathrm{~m}, 2 \mathrm{H}), 1.02-1.05(\mathrm{t}, 3 \mathrm{H}$, 
$\mathrm{J}=7.5 \mathrm{~Hz}) .{ }^{13} \mathrm{C}$ NMR $\left(125 \mathrm{MHz}, \mathrm{CDCl}_{3}, 25^{\circ} \mathrm{C}\right): \delta 162.2,161.3,155.3,152.5,125.4,113.4$, 112.6, 111.8, 101.3, 70.1, 22.3, 18.6, 10.4. DART-HRMS: $\mathrm{m} / \mathrm{z}$ calcd. for $\mathrm{C}_{13} \mathrm{H}_{14} \mathrm{O}_{3}[\mathrm{M}+\mathrm{H}]^{+}$: 219.10; Found: 219.10.

7-butoxy-4-methylcoumarin (7-BuMC)—Colorless solid, 23\% yield. ${ }^{1} \mathrm{H}$ NMR (500 $\left.\mathrm{MHz}, \mathrm{CDCl}_{3}, 25{ }^{\circ} \mathrm{C}\right): \delta$ 7.47-7.48 (d, 1H, J=5 Hz), 6.84-6.85 (d, 1H, J=5 Hz), $6.80(\mathrm{~s}, 1 \mathrm{H})$, $6.12(\mathrm{~s}, 1 \mathrm{H}), 4.00-4.03(\mathrm{t}, 2 \mathrm{H}, \mathrm{J}=7.5 \mathrm{~Hz}), 2.39(\mathrm{~s}, 3 \mathrm{H}), 1.78-1.81(\mathrm{~m}, 2 \mathrm{H}), 1.48-1.52(\mathrm{~m}, 2 \mathrm{H})$, 0.97-1.00 (t, 3H, J=7.5 Hz). ${ }^{13} \mathrm{C}$ NMR $\left(125 \mathrm{MHz}, \mathrm{CDCl}_{3}, 25^{\circ} \mathrm{C}\right): \delta 162.5,161.6,155.6$, 152.7, 125.6, 113.6, 112.9, 112.1, 101.6, 68.5, 31.2, 19.4, 18.9, 14.04. DART-HRMS: m/z calcd. for $\mathrm{C}_{14} \mathrm{H}_{16} \mathrm{O}_{3}[\mathrm{M}+\mathrm{H}]^{+}$: 233.11; Found: 233.11 .

7-propoxy-4-(trifluoromethyl)coumarin (7-PrFC)—Colorless solid, 50\% yield. ${ }^{1} \mathrm{H}$ NMR $\left(500 \mathrm{MHz}, \mathrm{CDCl}_{3}, 25^{\circ} \mathrm{C}\right): \delta$ 7.59-7.61 (d, $\left.1 \mathrm{H}, \mathrm{J}=10 \mathrm{~Hz}\right), 6.88-6.90(\mathrm{~d}, 1 \mathrm{H}, \mathrm{J}=10 \mathrm{~Hz})$, $6.84(\mathrm{~s}, 1 \mathrm{H}), 6.59(\mathrm{~s}, 1 \mathrm{H}), 3.98-4.00(\mathrm{t}, 2 \mathrm{H}, \mathrm{J}=5 \mathrm{~Hz}), 1.82-1.86(\mathrm{~m}, 2 \mathrm{H}), 1.03-1.06(\mathrm{t}, 3 \mathrm{H}$, $\mathrm{J}=7.5 \mathrm{~Hz}) .{ }^{13} \mathrm{C} \mathrm{NMR}\left(125 \mathrm{MHz}, \mathrm{CDCl}_{3}, 25^{\circ} \mathrm{C}\right): \delta 163.4,159.7,156.7,141.7,126.6,120.5$, 114.1, 112.4, 107.1, 102.1, 70.6, 22.5, 10.7. DART-HRMS: $\mathrm{m} / \mathrm{z}$ calcd. for $\mathrm{C}_{13} \mathrm{H}_{11} \mathrm{~F}_{3} \mathrm{O}_{3}$ [M $+\mathrm{H}]^{+}:$273.07; Found: 273.07 .

7-butoxy-4-(trifluoromethyl)coumarin (7-BuFC)—Colorless solid, $81 \%$ yield. ${ }^{1} \mathrm{H}$ NMR (500 MHz, $\left.\mathrm{CDCl}_{3}, 25^{\circ} \mathrm{C}\right): 87.59-7.60(\mathrm{~d}, 1 \mathrm{H}, \mathrm{J}=5 \mathrm{~Hz}), 6.88-6.89$ (d, $\left.1 \mathrm{H}, \mathrm{J}=5 \mathrm{~Hz}\right)$, $6.84(\mathrm{~s}, 1 \mathrm{H}), 6.58(\mathrm{~s}, 1 \mathrm{H}), 4.01-4.04(\mathrm{t}, 2 \mathrm{H}, \mathrm{J}=7.5 \mathrm{~Hz}), 1.78-1.81(\mathrm{~m}, 2 \mathrm{H}), 1.47-1.51(\mathrm{~m}, 2 \mathrm{H})$, 0.96-0.99 (t, 3H, J=7.5 Hz). ${ }^{13} \mathrm{C}$ NMR $\left(125 \mathrm{MHz}, \mathrm{CDCl}_{3}, 25{ }^{\circ} \mathrm{C}\right): \delta 163.1,159.4,156.3$, 141.6, 126.1, 120.4, 113.6, 111.9, 106.7, 101.7, 68.5, 30.8, 19.1, 13.6. DART-HRMS: m/z calcd. for $\mathrm{C}_{14} \mathrm{H}_{13} \mathrm{~F}_{3} \mathrm{O}_{3}[\mathrm{M}+\mathrm{H}]^{+}$: 287.08; Found: 287.08 .

7-(2-chloroethoxy)-4-(trifluoromethyl)coumarin (7-CIEFC)-Colorless solid, 17\% yield. ${ }^{1} \mathrm{H}$ NMR $\left(500 \mathrm{MHz}, \mathrm{CDCl}_{3}, 25{ }^{\circ} \mathrm{C}\right): \delta 7.64-7.66(\mathrm{~d}, 1 \mathrm{H}, \mathrm{J}=10 \mathrm{~Hz}), 6.94-6.96(\mathrm{~d}, 1 \mathrm{H}$, $\mathrm{J}=10 \mathrm{~Hz}), 6.88(\mathrm{~s}, 1 \mathrm{H}), 6.64(\mathrm{~s}, 1 \mathrm{H}), 4.30-4.33(\mathrm{t}, 2 \mathrm{H}, \mathrm{J}=7.5 \mathrm{~Hz}), 3.85-3.87$ (t, 2H, J=5 $\mathrm{Hz}) .{ }^{13} \mathrm{C} \mathrm{NMR}\left(125 \mathrm{MHz}, \mathrm{CDCl}_{3}, 25{ }^{\circ} \mathrm{C}\right): \delta 162.1,159.2,156.3,141.7,126.6,120.5,113.6$, 112.9, 107.7, 102.2, 68.6, 41.4. DART-HRMS: $\mathrm{m} / \mathrm{z}$ calcd. for $\mathrm{C}_{12} \mathrm{H}_{8} \mathrm{ClF}_{3} \mathrm{O}_{3}[\mathrm{M}+\mathrm{H}]^{+}$: 293.01; Found: 293.01.

7-(2-bromoethoxy)-4-(trifluoromethyl)coumarin (7-BrEFC)—Colorless solid, 36\% yield. ${ }^{1} \mathrm{H}$ NMR $\left(500 \mathrm{MHz}, \mathrm{CDCl}_{3}, 25^{\circ} \mathrm{C}\right): \delta 7.64-7.66(\mathrm{~d}, 1 \mathrm{H}, \mathrm{J}=10 \mathrm{~Hz}), 6.94-6.96(\mathrm{~d}, 1 \mathrm{H}$, $\mathrm{J}=10 \mathrm{~Hz}$ ), $6.88(\mathrm{~s}, 1 \mathrm{H}), 6.64(\mathrm{~s}, 1 \mathrm{H}), 4.36-4.39$ (t, 2H, J=7.5 Hz), 3.66-3.69 (t, 2H, J=7.5 $\mathrm{Hz}) .{ }^{13} \mathrm{C} \mathrm{NMR}\left(125 \mathrm{MHz}, \mathrm{CDCl}_{3}, 25^{\circ} \mathrm{C}\right): \delta 162.2,159.4,156.5,141.6,126.8,120.5,113.8$, 113.1, 107.9, 102.5, 68.6, 28.4. DART-HRMS: $\mathrm{m} / \mathrm{z}$ calcd. for $\mathrm{C}_{12} \mathrm{H}_{8} \mathrm{BrF}_{3} \mathrm{O}_{3}[\mathrm{M}+\mathrm{H}]^{+}$: 336.96; Found: 336.96.

\section{Enzymatic Assays}

The standard NADPH-dependent assays for $O$-dealkylation of 7-alkoxycoumarin, 7alkoxy-4-methylcoumarin, and 7-alkoxy-4-(trifluoromethyl)coumarin series were performed as described previously $(30,40,41)$. The reconstituted system contained the purified CYP enzyme with rat NADPH-cytochrome $\mathrm{P} 450$ reductase and rat cytochrome $b_{5}$ at a molar ratio of 1:4:2. Reactions using 7-alkoxy-4-(trifluoromethyl)coumarin series substrates were 
carried out in a $100 \mu \mathrm{L}$ final volume with substrate at varying concentrations $(0 \sim 300 \mu \mathrm{M})$. Reactions were preincubated for $3 \mathrm{~min}$ at $37^{\circ} \mathrm{C}$ in buffer containing $50 \mathrm{mM}$ HEPES (pH 7.4) and $15 \mathrm{mM} \mathrm{MgCl}_{2}$ before initiation of the reaction by addition of NADPH to a final concentration of $1 \mathrm{mM}$. After incubation for $5 \mathrm{~min}$ at $37^{\circ} \mathrm{C}$, the reaction was quenched by the addition of cold acetonitrile $(50 \mu \mathrm{L})$. For detection of 7-HFC, a $50 \mu \mathrm{L}$ aliquot of the reaction mixture was transferred into $950 \mu \mathrm{L}$ of $0.1 \mathrm{M}$ Tris ( $\mathrm{pH} 9.0)$, and fluorescence was determined with $\lambda_{\mathrm{ex}}=410 \mathrm{~nm}$ and $\lambda_{\mathrm{em}}=510 \mathrm{~nm}$ using a Hitachi F2000 fluorescence spectrophotometer (Tokyo, Japan).

Reactions using 7-alkoxycoumarin and 7-alkoxy-4-methylcoumarin series substrates were performed in the buffer containing $50 \mathrm{mM}$ HEPES (pH 7.4) and $15 \mathrm{mM} \mathrm{MgCl}_{2}$ in a $100 \mu \mathrm{L}$ final volume and substrate at varying concentrations $(0 \sim 300 \mu \mathrm{M})$. After a similar preincubation and initiation by addition of NADPH, the reaction proceeded for $10 \mathrm{~min}$ at $37{ }^{\circ} \mathrm{C}$ and was quenched by addition of $25 \mu \mathrm{L} 2 \mathrm{M} \mathrm{HCl}$. The entire reaction was extracted with $450 \mu \mathrm{L}$ of chloroform and centrifuged at $3000 \times g$ for $5 \mathrm{~min}$. After transferring $300 \mu \mathrm{L}$ of the organic layer to a clean test tube, the mixture was extracted with $1 \mathrm{~mL} 30 \mathrm{mM}$ sodium borate ( $\mathrm{pH}$ 9.2) followed by centrifugation for $5 \mathrm{~min}$ at $3000 \times \mathrm{g}$. A $900 \mu \mathrm{L}$ aliquot of the aqueous layer was transferred to a clean test tube, and the fluorescence was measured at $\lambda_{\mathrm{ex}}=370 \mathrm{~nm}$ for $7-\mathrm{HC}$ and $\lambda_{\mathrm{ex}}=360 \mathrm{~nm}$ for $7-\mathrm{HMC}$ and $\lambda_{\mathrm{em}}=450 \mathrm{~nm}$ for both products using a Hitachi F2000 fluorescence spectrophotometer.

In all assays, calibration was performed daily by measuring the intensity of fluorescence in the same reaction buffer containing 7-HC, 7-HMC or 7-HFC at concentrations from 0 to 2 $\mu \mathrm{M}$. The $K_{\mathrm{M}}$ and $k_{\text {cat }}$ values were determined by regression analysis with Igor Pro 6.35 (WaveMetrics) using the Michaelis-Menten or Hill equation.

\section{Crystallization and Data Collection}

Following purification, pooled protein was diluted to a final concentration of $18 \mu \mathrm{M}$ by addition of buffer containing $50 \mathrm{mM}$ potassium phosphate $\left(\mathrm{pH} 7.4\right.$ at $\left.4{ }^{\circ} \mathrm{C}\right), 500 \mathrm{mM}$ sucrose, $500 \mathrm{mM} \mathrm{NaCl}, 1 \mathrm{mM}$ EDTA, and $0.2 \mathrm{mM}$ DTT. (+)-a-pinene dissolved in acetone was added to $2 \mathrm{~B} 6 \mathrm{Y} 244 \mathrm{~W}$ to a final concentration of $180 \mu \mathrm{M}$. The diluted enzymes were incubated overnight at $4{ }^{\circ} \mathrm{C}$ on ice. Protein was concentrated by centrifugation using $50-\mathrm{kDa}$ cutoff Amicon ultrafiltration devices (Millipore). The procedure was repeated twice before concentrating the protein to the final concentration of $300 \mu \mathrm{M}$ for $2 \mathrm{~B} 6 \mathrm{Y} 244 \mathrm{~W}$ and $500 \mu \mathrm{M}$ for 2B4 F244W. The concentrated CYP2B6 Y244W protein-ligand complex was then supplemented with $4.8 \mathrm{mM} \mathrm{CYMAL-5,} 300 \mu \mathrm{M}$ (+)-a-pinene, and 0.028\% (w/v) FA-4. CYP2B4 F244W-ligand free was supplemented with $4.8 \mathrm{mM} \mathrm{CYMAL-5}$, and $0.056 \%$ (w/v) FA-4. Prior to screening, samples were filtered using $0.22 \mu \mathrm{m}$ Ultrafree-MC centrifugal filters (Millipore), and crystal screening was performed by the sitting-drop vapor diffusion method. Crystals of the CYP2B6 Y244W (+)-a-pinene complex were obtained from the Hampton Research Crystal Screen 2 in 0.1 M HEPES pH 7.5 and 20\% w/v polyethylene glycol 10,000 after 3-4 days. Crystals of the CYP2B4 F244W in the absence of ligand were obtained from the Rigaku Wizard 3 screen in 0.1 M HEPES pH 7.0 and 10\% w/v polyethylene glycol 6,000 after 3-4 days. Crystals were transferred to the mother liquor containing $20 \%(\mathrm{v} / \mathrm{v})$ sucrose for cryoprotection before flash freezing them in liquid 
nitrogen. Crystallographic data for CYP2B6 Y244W-(+)-a-pinene were collected remotely at Stanford Synchrotron Radiation Lightsource (SSRL) on beam line 12-1 using $1^{\circ}$ oscillations over 120 frames and $1 \mathrm{~s}$ exposures with a ADSC Quantum 315r CCD detector at $100 \mathrm{~K}$ (42). CYP2B4 F244W ligand free data were collected remotely at SSRL beam line 7-1 using $1^{\circ}$ oscillations over 240 frames and $10 \mathrm{~s}$ exposures with a ADSC Quantum 315r CCD detector at $100 \mathrm{~K}$. Crystals of CYP2B6 Y244W-(+)-a-pinene diffracted to $2.2 \AA$ resolution and CYP2B4 F244W ligand free diffracted to $3.0 \AA$ A resolution. Data were integrated using iMOSFLM (43) and scaled using SCALA in CCP4 (44).

\section{Structure Determination and Refinement}

The structure of CYP2B6 Y244W in complex with (+)-a-pinene was determined using the coordinates of the CYP2B6-(+)-a-pinene structure (PDB ID: 4I91) as a starting model in the molecular replacement program Phaser (45) from the CCP4 software suite (44). The solvent content of $61.7 \%$ was determined by the Matthews coefficient analysis, assuming the presence of one molecule in the asymmetric unit. The output model from Phaser, with the space group $P 3_{2} 21$, was subjected to rigid body and restrained refinement in REFMAC5 (46) in CCP4 (44). The model was built manually in COOT (47) using $2 F_{\mathrm{o}}-F_{\mathrm{c}}$ and $F_{\mathrm{o}}-F_{\mathrm{c}}$ electron density maps contoured at $1-\sigma$ and $3-\sigma$, respectively. PRODRG server was used to make the library description for (+)-a-pinene (48). Iterative refinement was continued until the $R$-factor and $R_{\text {free }}$ of 0.17 and 0.23 , respectively, were achieved. The model was validated by MOLPROBITY (49), which ranked the structure in the $98^{\text {th }}$ percentile among structures of comparable resolution. There were no Ramachandran outliers or bad bond lengths or angles in the final model. The crystal structure contained a total of 675 molecules of water, two molecules of CYMAL-5 detergent, and protein residues from 28 to 492 with the terminal residue being the first histidine of the C-terminal 4-His-tag. Coordinates and structure factors were deposited in the Protein Data Bank (PDB ID: 4ZV8). In parallel, the structure of CYP2B4 F244W in the absence of ligand was determined at $3.0 \AA$ resolution, and Matthews coefficient analysis indicated the presence of two molecules in the asymmetric unit. The CYP2B4 ligand free structure (PDB ID: 3MVR) was used as a starting model for molecular replacement in Phaser. Iterative refinement in REFMAC5 and model building in COOT was continued until the $R$-factor (0.23) and $R$-free (0.28) stopped improving. The crystal structure contained a total of 14 molecules of water, four molecules of CYMAL-5 detergent, and protein residues from 28 to 492 with the terminal residue being the first histidine of the C-terminal 4-His-tag. MOLPROBITY analysis ranked the structure in the $98^{\text {th }}$ percentile among structures of comparable resolution. Coordinates and structure factors were deposited in the Protein Data Bank (PDB ID: 5EM4). The refinement statistics for both structures are summarized in Table S2.

\section{Results}

\section{Determinants of CYP2B4 and CYP2B6 Coumarin Substrate Preference}

A series of alkyl ethers of 7-HC with varying alkyl chain length was previously used to probe the active sites of CYP2B1 and CYP3A4 $(28,29,31)$. Furthermore, 4-substituted-7ethyoxycoumarins, including 7-EC and 7-EFC, have been used as model substrates of CYP2B enzymes. In the present investigation three series of 4-substituted 7- 
alkoxycoumarins (50) were used as potential probes of the functional potential importance of the peripheral pocket in CYP2B4 and CYP2B6 (Figure 2). These allowed assessment of the functional effect of altering the length of the 7-alkoxy chain and varying the substituent located at the 4-position of the coumarin moiety. Tables 1 and 2 summarize the steady-state kinetics results for $O$-dealkylation of these substrates by CYP2B4 and CYP2B6, respectively. In general, increased 7-alkoxy chain length decreased $k_{\text {cat }}$ and $K_{\mathrm{M}}$ in concert, so that catalytic efficiency $\left(k_{\mathrm{cat}} / K_{\mathrm{M}}\right)$ remained similar within each set of 4-substituted compounds. The exception occurred in the 4-trifluoromethyl substituted series, where dealkylation of 7-BuFC was undetectable with either enzyme, and catalytic efficiency of 7PrFC $O$-dealkylation by CYP2B6 was 7-fold lower than that of 7-EFC.

With the 7-ethoxy compounds, altering the 4-substitutent on the coumarin core from proton (-H) to electron-donating group $\left(-\mathrm{CH}_{3}\right)$ decreased the $k_{\mathrm{cat}}$ and $K_{\mathrm{M}}$, resulting in little change in catalytic efficiency of $O$-dealkylation by CYP2B4 and CYP2B6. Conversely, substitution of the electron-donating 4-methyl with an electron-withdrawing 4-trifluoromethyl group greatly increased $k_{\text {cat }}$ for $O$-dealkylation coupled with a further reduction in $K_{\mathrm{M}}$. The 4trifluoromethyl substitution for the 4-methyl increases the bulk of this group, increases the lipophilicity of the molecule, and alters the hydrogen bonding character of the group from donor to weak acceptor (51). The increase in bulk at the 4-carbon may preferentially orient the 7-alkoxy group toward the heme iron for productive $O$-dealkylation. This combination of changes leads to $\sim 20$ - and 65-fold increases in catalytic efficiency of $O$-deethylation of 7EFC versus 7-EC or 7-EMC for CYP2B4 and 2B6, respectively. For 7-propoxy compounds, an increase in catalytic efficiency is seen across the set of compounds. In CYP2B4, this increase in catalytic efficiency is solely due to decreases in $K_{\mathrm{M}}$ upon addition of the 4methyl and 4-trifluoromethyl groups. However, in CYP2B6 the addition of a 4-methyl group increases $k_{\text {cat }}$ with only a small decrease in $K_{\mathrm{M}}$, but changing the 4-methyl to a 4trifluoromethyl group leads to a sharp decrease in $K_{\mathrm{M}}$ and virtually no change in $k_{\mathrm{cat}}$. With both enzymes, the lowest $K_{\mathrm{M}}$ among all the compounds tested is observed with 7-PrFC. The catalytic efficiency of CYP2B4 catalyzed $O$-debutylation is virtually unchanged with the addition of the 4-methyl moiety, whereas CYP2B6 is more efficient due to a lower $K_{\mathrm{M}}$.

\section{Effect of Substrate Halogenation on CYP2B Substrate Specificity}

To develop even more potent ligands, the effect of halogenating the terminus of the 7-ethoxy chain of 7-EFC was analyzed (Figure 2). Chlorine and bromine were selected since 1) CYP2B enzymes appear to form halogen bonds readily, especially $-\mathrm{Cl}-\pi$ bonds (15), and 2) non-coplanar congeners from two groups of persistent halogenated organic pollutants, polychlorinated biphenyls and polybrominated diphenyl ethers, are preferentially metabolized by CYP2B enzymes $(52,53)$. The strength of halogen bonds is roughly correlated with the electrostatic potential on the halogen atom. Fluorine was not used, since organofluorines generally do not form halogen bonds relevant to medicinal chemistry (54, 55). As shown in Tables 3 and 4 , the $K_{\mathrm{M}}$ for $O$-dealkylation by both enzymes was decreased 3 -fold upon bromination, and 11-fold upon chlorination in the case of CYP2B4. However, catalytic efficiency decreased in all cases due to 10-20 fold decreased in $k_{\text {cat }}$. 


\section{Effect of Modifying Residues 194 and 244 on CYP2B6 and CYP2B4 Function}

Mutants were made in CYP2B4 and 2B6 in an attempt to block off the peripheral pocket by altering side-chain polarity at residue $194(\mathrm{~V} / \mathrm{E} \rightarrow \mathrm{Q})$ or bulk at residue $244(\mathrm{~F} / \mathrm{Y} \rightarrow \mathrm{W})$ (Figures 3A, 4A). $O$-dealkylation of 7-EFC and its halogenated derivatives was used to characterize function (Tables 3 and 4). With the mutants at position 194, relatively little effect was observed on 7-EFC $O$-dealkylation, whereas CYP2B4 F244W and CYP2B6 Y244W showed 4-and 2-fold increases in catalytic efficiency of 7-EFC $O$-dealkylation, respectively, primarily due to increased $k_{\text {cat }}$. The effects of the mutations were even more striking with 7-ClEFC and 7-BrEFC. With CYP2B4 the increased catalytic efficiency of both mutants is due to 2-10 fold increases in $k_{\text {cat }}$ along with essentially unaltered $K_{\mathrm{M}}$. Conversely in CYP2B6 7-ClEFC and 7-BrEFC $O$-dealkylation, the 4-9 fold increase in catalytic efficiency is due to much lower $K_{\mathrm{M}}$ values with little change in $k_{\text {cat }}$.

\section{Structures of CYP2B6 Y244W and CYP2B4 F244W}

Attempts to crystallize CYP2B6 or CYP2B6 Y244W in the absence of ligand or in the presence of the most potent coumarin derivatives were unsuccessful. Therefore, CYP2B6 Y244W was crystallized in the presence of the monoterpene (+)-a-pinene, for which binding affinity was unaltered [CYP2B6 WT $\left(K_{\mathrm{S}}=0.38 \mu \mathrm{M}\right)(27)$ and CYP2B6 Y244W $\left(K_{\mathrm{S}}=0.43\right.$ $\mu \mathrm{M})$ ]. Importantly, the mutant structure showed no CYMAL-5 in the peripheral pocket. An overlay of the new CYP2B6 Y244W-(+)-a-pinene complex (PDB ID: 4ZV8) reported here with the previously solved structure of the CYP2B6-(+)-a-pinene complex (PDB ID: 4I91) revealed significant differences in the orientation of residue side chains in the peripheral pocket presumably due to the lack of detergent (Figure 3A). Despite the significant differences in the peripheral pocket residues, the structures of CYP2B6 WT and CYP2B6 Y244W in complex with (+)-a-pinene revealed little difference in the orientation of active site side chains (Figure 3B). In parallel, structure determination of ligand free CYP2B4 F244W (PDB ID: 5EM4) revealed binding of CYMAL-5 in the peripheral pocket, similar to that observed in the ligand free structure of CYP2B4 WT (PDB ID: 3MVR), with little difference in the orientation of active site residues (Figure 4A-B). These results suggest that introduction of tryptophan at position 244 in CYP2B6 or CYP2B4 may or may not prevent CYMAL-5 binding, respectively, in the peripheral pocket of these enzymes. However, binding of CYMAL-5 in the peripheral pocket located in close vicinity of the active site likely does not influence the active site architecture. In addition to the similarity of the active site residue orientations, the similarity in orientation of the bound (+)-a-pinene in the CYP2B6 WT and Y244W complexes with and without CYMAL-5 in the peripheral pocket is indicative of little effect on binding of ligands in the catalytic chamber.

\section{Discussion}

CYP enzymes involved in mammalian detoxification generally metabolize a broad range of substrates. These enzymes are often relatively flexible and are capable of binding multiple ligand molecules simultaneously. This combination of properties can lead to non-MichaelisMenten kinetics of substrate oxidation (56). Structurally, multiple substrate molecules can bind at distinct locations within the distal heme pocket, as seen in the CYP2C8-cis-retinoic acid complex (PDB ID: 2NNH) (57) or ketoconazole complex of CYP3A4 (PDB ID: 
2V0M) (58). Alternatively, a ligand binding event may occur at a site outside the enzyme active site, as seen in the location of progesterone in complex with CYP3A4 (24). Many of the previously solved X-ray crystal structures of CYP2B4 and CYP2B6 demonstrated binding of CYMAL-5 in a peripheral pocket surrounded by the E-, F-, G-, and I-helices (14, 27, 59-62). Mutants within this peripheral pocket can greatly reduce enzyme activity (26). The current study focused on elucidating the structural consequences of CYMAL-5 binding in this peripheral pocket on the CYP2B4 or 2B6 active site and further exploring the effect of substrate halogenation on CYP2B enzyme activity.

Ligand binding at a peripheral site in CYP enzymes could alter substrate metabolism via several possible processes. Binding of ligand A could alter the turnover of ligand B, as seen in the interaction of testosterone with CYP3A4 for two molecules of one substrate or in the interaction of progesterone and carbamazepine with CYP3A4 for multiple substrates (63-65). Binding of ligand A could alter interactions between CYP enzymes, and modify oxidation of ligand B, as has been suggested in the case of CYP3A4, 3A5 or 2E1 $(24,66)$. Finally, binding of ligand A could physically impede structural compensations necessary for optimal binding of ligand B in the CYP enzyme active site. In this case, the cyclohexyl group of CYMAL-5 bound in the CYP2B4 or 2B6 peripheral pocket would likely prevent changes in the orientation of the I-helix, preventing optimal ligand orientation for oxidation (27). Furthermore, introduction of extra bulk via mutation of select residues to tryptophan severely hampered enzyme activity in both CYP2B4 and 2B6 (26). The snapshots from comparison of the X-ray crystal structures of ligand free CYP2B4 and CYP2B4 F244W and of the (+)-a-pinene bound complexes of CYP2B6 and CYP2B6 Y244W indicated that neither CYMAL-5 nor the distal mutation alters active site topology. These results do not rule out differences in solution structural dynamic behavior between the respective WT CYP2B enzymes and the corresponding F/Y244W mutant, either in altering the structural response of the protein upon ligand binding or in altering the equilibrium between different CYP2B conformations in solution.

In X-ray crystal structures of CYP2B4 and CYP2B6 in complex with 4-CPI or amlodipine, residues 202 and 241 appear to form a $\mathrm{C}-\mathrm{H} / \pi$ bond between the aromatic ring of $\mathrm{F} 202$ and the I241 $\delta$-carbon (Figure 5A-B). This type of weak hydrogen bond is involved in multiple phenomena in organic and biological chemistry, from reaction selectivity to protein conformational stabilization (67). In the CYP2B4 or CYP2B6 F202W mutants the geometry of this interaction is likely altered due to the increased steric bulk of the tryptophan indole ring, and the indole ring of the $\mathrm{I} 241 \mathrm{~W}$ mutant in CYP2B4 could interact with the phenyl ring of F202 via arene-arene $\pi-\pi$ interactions. In either case the distance between the F- and Ghelices would be altered, and any resultant interaction between residues 202 and 241 would change the relative orientations of the F- and G-helices. In contrast, substitution of tryptophan at residue 244 could allow for further stabilization of the F-G cassette by creating additional hydrogen bonding interaction involving the pairs V194/F244W and V194Q/F244 in CYP2B4 and E194/Y244W and E194Q/Y244 in CYP2B6.

While hydrogen bonding $(\mathrm{C}-\mathrm{H} / \pi)$ appears to provide structural stability to CYP2B enzymes, halogen bonding is implicated in selectivity of ligand binding to CYP2B enzymes.

Structures of multiple proteins in complex with their respective ligand demonstrate the 
prevalence of halogen- $\pi$ bonding in X-ray crystal structures $(15,50,68)$. In this light the implications of the modest effects of the CYP2B4 F244W (4-fold) and CYP2B6 Y244W (2fold) mutations on the catalytic efficiency of 7-EFC metabolism become clearer. With both mutants the efficiency of $O$-dealkylation of the halogenated substrates increased to between 5- and 8-fold greater than the respective WT enzyme. Interestingly, in other enzyme systems, introduction of $-\mathrm{F}$ does not alter ligand affinity, while heavy halogens $(-\mathrm{Cl},--\mathrm{Br}$, $-\mathrm{I})$ do increase affinity $(69,70)$. Additionally, introduction of heavy halogens into drug leads has led to greater likelihood of launching a compound as an approved therapeutic than inclusion of a $-\mathrm{F}$ does, possibly as a result of improved pharmacokinetic properties (71).

In conclusion, a comparison of (+)-a-pinene bound CYP2B6 Y244W and ligand free CYP2B4 F244W with the previously solved CYP2B6 WT-(+)-a-pinene and the ligand free CYP2B4 WT structures, respectively, revealed that the presence or absence of CYMAL-5 binding in the peripheral pocket does not alter active site topology. However, the absence of CYMAL-5 in the CYP2B6 Y244W complex led to significant differences in the orientation of residue side chains in the peripheral pocket and near its access region. The side chain of F296 protruded into the pocket, while residues E194 and Y244W contributed to block off the pocket. Additionally, we investigated the utility of 7-alkoxycoumarin derivatives as substrate probes of CYP2B enzyme function. The results demonstrated that the substituent at the 4-position and the side chain length at the 7-position have a significant influence on the metabolism of coumarin derivatives by CYP2B enzymes. Altering the bulk at residue 244 increased catalytic efficiency of 7-EFC $O$-dealkylation in both CYP2B4 and CYP2B6 as reflected in an increase in $k_{\text {cat }}$. Introduction of a halogen at the 2-position of the 7-ethoxy side chain of 7-EFC led to a decrease in catalytic efficiency of $O$-dealkylation by both enzymes and accentuated the positive effects on activity of the amino acid substitutions at positions 194 and 244. Intriguingly, the increases in catalytic efficiency observed with these mutants are diametrically opposite to the detrimental effects of peripheral pocket mutations at residues 202 and 241 and lack of effect of a substitution at position 195 observed previously (26). The substrate preference profiles obtained in this study provide insights into the effects of substrate size and halogen substitution on CYP2B catalysis. Further studies using a combination of site-directed mutagenesis, solution biophysical methods, and substrate metabolism will improve our understanding of halogenated substrate recognition by CYP2B enzymes and possibly other xenobiotic metabolizing CYP enzymes.

\section{Supplementary Material}

Refer to Web version on PubMed Central for supplementary material.

\section{Acknowledgments}

We thank Dr. M. Kyle Hadden and Dr. Albert M. DeBerardinis (Division of Medicinal Chemistry, Department of Pharmaceutical Sciences, University of Connecticut) for kindly providing and setting up the synthetic apparatus. We also thank the staff at Stanford Synchrotron Radiation Light source, operated by Stanford University on behalf of the United States Department of Energy, Office of Basic Energy Sciences, for assistance with the beam line.

Funding Sources: This research was supported by the National Institutes of Health [Grant R01-ES003619] (to J.R.H.), and [Grant R01-GM098538] (to Q.Z.). 


\section{References}

1. Rydberg P, Vasanthanathan P, Oostenbrink C, Olsen L. Fast prediction of cytochrome P450 mediated drug metabolism. ChemMedChem. 2009; 4:2070-2079. [PubMed: 19852016]

2. Rydberg P, Olsen L. Predicting drug metabolism by cytochrome P450 2C9: comparison with the 2D6 and 3A4 isoforms. ChemMedChem. 2012; 7:1202-1209. [PubMed: 22593031]

3. Halpert JR. Structure and function of cytochromes P450 2B: from mechanism-based inactivators to X-ray crystal structures and back. Drug Metab Dispos. 2011; 39:1113-1121. [PubMed: 21502194]

4. Johnson EF, Connick JP, Reed JR, Backes WL, Desai MC, Xu L, Estrada DF, Laurence JS, Scott EE. Correlating structure and function of drug-metabolizing enzymes: progress and ongoing challenges. Drug Metab Dispos. 2014; 42:9-22. [PubMed: 24130370]

5. Anzenbacher P, Anzenbacherova E, Lange R, Skopalik J, Otyepka M. Active sites of cytochromes P450: What are they like? Acta Chim Slov. 2008; 55:63-66.

6. Poulos TL. Structural biology of heme monooxygenases. Biochem Bioph Res Co. 2005; 338:337345.

7. Lewis DFV, Ito Y, Lake BG. Quantitative structure-activity relationships (QSARs) for inhibitors and substrates of CYP2B enzymes: Importance of compound lipophilicity in explanation of potency differences. J Enzym Inhib Med Ch. 2010; 25:679-684.

8. Ekins S, Iyer M, Krasowski MD, Kharasch ED. Molecular characterization of CYP2B6 substrates. Curr Drug Metab. 2008; 9:363-373. [PubMed: 18537573]

9. Mo SL, Liu YH, Duan W, Wei MQ, Kanwar JR, Zhou SF. Substrate specificity, regulation, and polymorphism of human cytochrome P450 2B6. Curr Drug Metab. 2009; 10:730-753. [PubMed: 19702527]

10. Zhao Y, Halpert JR. Structure-function analysis of cytochromes P450 2B. BBA-Gen Subjects. 2007; 1770:402-412.

11. Wilderman PR, Halpert JR. Plasticity of CYP2B enzymes: structural and solution biophysical methods. Curr Drug Metab. 2012; 13:167-176. [PubMed: 22208531]

12. Domanski TL, Halpert JR. Analysis of mammalian cytochrome P450 structure and function by site-directed mutagenesis. Curr Drug Metab. 2001; 2:117-137. [PubMed: 11469721]

13. Muralidhara BK, Halpert JR. Thermodynamics of ligand binding to P450 2B4 and P450eryF studied by isothermal titration calorimetry. Drug Metab Rev. 2007; 39:539-556. [PubMed: 17786637]

14. Shah MB, Wilderman PR, Pascual J, Zhang QH, Stout CD, Halpert JR. Conformational adaptation of human cytochrome P450 2B6 and rabbit cytochrome P450 2B4 revealed upon binding multiple amlodipine molecules. Biochemistry. 2012; 51:7225-7238. [PubMed: 22909231]

15. Shah MB, Wilderman PR, Liu J, Jang HH, Zhang Q, Stout CD, Halpert JR. Structural and biophysical characterization of human cytochromes P450 2B6 and 2A6 bound to volatile hydrocarbons: analysis and comparison. Molecular pharmacology. 2015; 87:649-659. [PubMed: 25585967]

16. Wang HB, Tompkins LM. CYP2B6: new insights into a historically overlooked cytochrome P450 isozyme. Curr Drug Metab. 2008; 9:598-610. [PubMed: 18781911]

17. Zhou SF, Liu JP, Chowbay B. Polymorphism of human cytochrome P450 enzymes and its clinical impact. Drug Metab Rev. 2009; 41:89-295. [PubMed: 19514967]

18. Zanger UM, Klein K. Pharmacogenetics of cytochrome P450 2B6 (CYP2B6): advances on polymorphisms, mechanisms, and clinical relevance. Front Genet. 2013; 4:24. [PubMed: 23467454]

19. Kumar S, Chen CS, Waxman DJ, Halpert JR. Directed evolution of mammalian cytochrome P450 2B1: Mutations outside of the active site enhance the metabolism of several substrates, including the anticancer prodrugs cyclophosphamide and ifosfamide. J Biol Chem. 2005; 280:19569-19575. [PubMed: 15774478]

20. Wilderman PR, Gay SC, Jang HH, Zhang Q, Stout CD, Halpert JR. Investigation by site-directed mutagenesis of the role of cytochrome P450 2B4 non-active-site residues in protein-ligand interactions based on crystal structures of the ligand-bound enzyme. Febs J. 2012; 279:1607-1620. [PubMed: 22051155] 
21. Ekins S, Wrighton SA. The role of CYP2B6 in human xenobiotic metabolism. Drug Metab Rev. 1999; 31:719-754. [PubMed: 10461547]

22. Koley AP, Buters JTM, Robinson RC, Markowitz A, Friedman FK. CO binding-kinetics of human cytochrome-P450 3A4 - specific interaction of substrates with kinetically distinguishable conformers. J Biol Chem. 1995; 270:5014-5018. [PubMed: 7890608]

23. Davydov DR, Halpert JR. Allosteric P450 mechanisms: multiple binding sites, multiple conformers or both? Expert Opin Drug Metab Toxicol. 2008; 4:1523-1535. [PubMed: 19040328]

24. Williams PA, Cosme J, Vinkovic DM, Ward A, Angove HC, Day PJ, Vonrhein C, Tickle IJ, Jhoti $\mathrm{H}$. Crystal structures of human cytochrome P450 3A4 bound to metyrapone and progesterone. Science. 2004; 305:683-686. [PubMed: 15256616]

25. Denisov IG, Mak PJ, Grinkova YV, Bastien D, Berube G, Sligar SG, Kincaid JR. The use of isomeric testosterone dimers to explore allosteric effects in substrate binding to cytochrome P450 CYP3A4. J Inorg Biochem. 2015 In Press. 10.1016/j.jinorgbio.2015.1012.1019

26. Jang HH, Liu J, Lee GY, Halpert JR, Wilderman PR. Functional importance of a peripheral pocket in mammalian cytochrome P450 2B enzymes. Arch Biochem Biophys. 2015; 584:61-69. [PubMed: 26319176]

27. Wilderman PR, Shah MB, Jang HH, Stout CD, Halpert JR. Structural and thermodynamic basis of (+)-a-pinene binding to human cytochrome P450 2B6. J Am Chem Soc. 2013; 135:10433-10440. [PubMed: 23786449]

28. Fang XJ, Kobayashi Y, Halpert JR. Stoichiometry of 7-ethoxycoumarin metabolism by cytochrome P450 2B1 wild-type and five active-site mutants. FEBS Lett. 1997; 416:77-80. [PubMed: 9369237]

29. Kobayashi Y, Fang X, Szklarz GD, Halpert JR. Probing the active site of cytochrome P450 2B1: metabolism of 7-alkoxycoumarins by the wild type and five site-directed mutants. Biochemistry. 1998; 37:6679-6688. [PubMed: 9578551]

30. Domanski TL, He YQ, Scott EE, Wang Q, Halpert JR. The role of cytochrome 2B1 substrate recognition site residues 115, 294, 297, 298, and 362 in the oxidation of steroids and 7alkoxycoumarins. Arch Biochem Biophys. 2001; 394:21-28. [PubMed: 11566023]

31. Khan KK, Halpert JR. Structure-function analysis of human cytochrome P450 3A4 using 7alkoxycoumarins as active-site probes. Arch Biochem Biophys. 2000; 373:335-345. [PubMed: 10620357]

32. Harlow GR, He YA, Halpert JR. Functional interaction between amino-acid residues 242 and 290 in cytochromes P-450 2B1 and 2B11. Biochim Biophys Acta. 1997; 1338:259-266. [PubMed: 9128144]

33. Holmans PL, Shet MS, Martin-Wixtrom CA, Fisher CW, Estabrook RW. The high-level expression in Escherichia coli of the membrane-bound form of human and rat cytochrome b5 and studies on their mechanism of function. Arch Biochem Biophys. 1994; 312:554-565. [PubMed: 8037471]

34. Lee SC, Bennett BC, Hong WX, Fu Y, Baker KA, Marcoux J, Robinson CV, Ward AB, Halpert JR, Stevens RC, Stout CD, Yeager MJ, Zhang Q. Steroid-based facial amphiphiles for stabilization and crystallization of membrane proteins. P Natl Acad Sci USA. 2013; 110:E1203-E1211.

35. Scott EE, Spatzenegger M, Halpert JR. A truncation of 2B subfamily cytochromes P450 yields increased expression levels, increased solubility, and decreased aggregation while retaining function. Arch Biochem Biophys. 2001; 395:57-68. [PubMed: 11673866]

36. Jang HH, Davydov DR, Lee GY, Yun CH, Halpert JR. The role of cytochrome P450 2B6 and 2B4 substrate access channel residues predicted based on crystal structures of the amlodipine complexes. Arch Biochem Biophys. 2014; 545:100-107. [PubMed: 24445070]

37. Omura T, Sato R. Carbon monoxide-binding pigment of liver microsomes. II. Solubilization purification and properties. J Biol Chem. 1964; 239:2379-2385. [PubMed: 14209972]

38. Sanchez-Recillas A, Navarrete-Vazquez G, Hidalgo-Figueroa S, Rios MY, Ibarra-Barajas M, Estrada-Soto S. Semisynthesis, ex vivo evaluation, and SAR studies of coumarin derivatives as potential antiasthmatic drugs. Eur J Med Chem. 2014; 77:400-408. [PubMed: 24681028]

39. Xiaobing C, Haitao X, Xiaoqiang S, Ting Z, Qi M, Yan J. Synthesis and fluorescent probes properties of a coumarin-based piperazine containing fluorine. Chinese J Org Chem. 2011; 31:544-547. 
40. He YQ, He YA, Halpert JR. Escherichia coli expression of site-directed mutants of cytochrome P450 2B1 from six substrate recognition sites: substrate specificity and inhibitor selectivity studies. Chem Res Toxicol. 1995; 8:574-579. [PubMed: 7548737]

41. Domanski TL, Schultz KM, Roussel F, Stevens JC, Halpert JR. Structure-function analysis of human cytochrome P-450 2B6 using a novel substrate, site-directed mutagenesis, and molecular modeling. J Pharmacol Exp Ther. 1999; 290:1141-1147. [PubMed: 10454488]

42. Soltis SM, Cohen AE, Deacon A, Eriksson T, Gonzalez A, McPhillips S, Chui H, Dunten P, Hollenbeck M, Mathews I, Miller M, Moorhead P, Phizackerley RP, Smith C, Song J, van dem Bedem H, Ellis P, Kuhn P, McPhillips T, Sauter N, Sharp K, Tsyba I, Wolf G. New paradigm for macromolecular crystallography experiments at SSRL: automated crystal screening and remote data collection. Acta Crystallogr D. 2008; 64:1210-1221. [PubMed: 19018097]

43. Leslie AGW. Integration of macromolecular diffraction data. Acta Crystallogr D. 1999; 55:16961702. [PubMed: 10531519]

44. Bailey S. The CCP4 Suite - Programs for protein crystallography. Acta Crystallogr D. 1994; 50:760-763. [PubMed: 15299374]

45. McCoy AJ, Grosse-Kunstleve RW, Adams PD, Winn MD, Storoni LC, Read RJ. Phaser crystallographic software. J Appl Crystallogr. 2007; 40:658-674. [PubMed: 19461840]

46. Murshudov GN, Vagin AA, Dodson EJ. Refinement of macromolecular structures by the maximum-likelihood method. Acta Crystallogr D. 1997; 53:240-255. [PubMed: 15299926]

47. Emsley P, Cowtan K. Coot: model-building tools for molecular graphics. Acta Crystallogr D. 2004; 60:2126-2132. [PubMed: 15572765]

48. van Aalten DMF, Bywater R, Findlay JBC, Hendlich M, Hooft RWW, Vriend G. PRODRG, a program for generating molecular topologies and unique molecular descriptors from coordinates of small molecules. J Comput Aid Mol Des. 1996; 10:255-262.

49. Chen VB, Arendall WB 3rd, Headd JJ, Keedy DA, Immormino RM, Kapral GJ, Murray LW, Richardson JS, Richardson DC. MolProbity: all-atom structure validation for macromolecular crystallography. Acta Crystallogr D. 2010; 66:12-21. [PubMed: 20057044]

50. Shah MB, Liu J, Huo L, Zhang Q, Dearing MD, Wilderman PR, Szklarz GD, Stout CD, Halpert JR. Structure-function analysis of mammalian CYP2B enzymes using 7-substituted coumarin derivatives as probes: utility of crystal structures and molecular modeling in understanding xenobiotic metabolism. Mol Pharmacol. 2016 In Press. 10.1124/mol.1115.102111

51. Müller K, Faeh C, Diederich F. Fluorine in pharmaceuticals: looking beyond intuition. Science. 2007; 317:1881-1886. [PubMed: 17901324]

52. Hrycay EG, Bandiera SM. Spectral interactions of tetrachlorobiphenyls with hepatic microsomal cytochrome p450 enzymes. Chem Biol Interact. 2003; 146:285-296. [PubMed: 14642740]

53. Kania-Korwel I, Hrycay EG, Bandiera SM, Lehmler HJ. 2,2',3,3',6,6'-Hexachlorobiphenyl (PCB 136) atropisomers interact enantioselectively with hepatic microsomal cytochrome $\mathrm{P} 450$ enzymes. Chem Res Toxicol. 2008; 21:1295-1303. [PubMed: 18494506]

54. Metrangolo P, Murray JS, Pilati T, Politzer P, Resnati G, Terraneo G. Fluorine-centered halogen bonding: a factor in recognition phenomena and reactivity. Cryst Growth Des. 2011; 11:42384246.

55. Wilcken R, Zimmermann MO, Lange A, Joerger AC, Boeckler FM. Principles and applications of halogen bonding in medicinal chemistry and chemical biology. J Med Chem. 2013; 56:1363-1388. [PubMed: 23145854]

56. Denisov IG, Frank DJ, Sligar SG. Cooperative properties of cytochromes P450. Pharmacol Ther. 2009; 124:151-167. [PubMed: 19555717]

57. Schoch GA, Yano JK, Sansen S, Dansette PM, Stout CD, Johnson EF. Determinants of cytochrome P450 2C8 substrate binding: structures of complexes with montelukast, troglitazone, felodipine, and 9-cis-retinoic acid. J Biol Chem. 2008; 283:17227-17237. [PubMed: 18413310]

58. Ekroos M, Sjögren T. Structural basis for ligand promiscuity in cytochrome P450 3A4. P Natl Acad Sci USA. 2006; 103:13682-13687.

59. Wilderman PR, Shah MB, Liu T, Li S, Hsu S, Roberts AG, Goodlett DR, Zhang Q, Woods VL Jr, Stout CD, Halpert JR. Plasticity of cytochrome P450 2B4 as investigated by hydrogen-deuterium 
exchange mass spectrometry and X-Ray crystallography. J Biol Chem. 2010; 285:38602-38611. [PubMed: 20880847]

60. Gay SC, Shah MB, Talakad JC, Maekawa K, Roberts AG, Wilderman PR, Sun L, Yang JY, Huelga SC, Hong WX, Zhang Q, Stout CD, Halpert JR. Crystal structure of a cytochrome P450 2B6 genetic variant in complex with the inhibitor 4-(4-chlorophenyl)imidazole at 2.0-A resolution. Mol Pharmacol. 2010; 77:529-538. [PubMed: 20061448]

61. Shah MB, Kufareva I, Pascual J, Zhang Q, Stout CD, Halpert JR. A structural snapshot of CYP2B4 in complex with paroxetine provides insights into ligand binding and clusters of conformational states. J Pharmacol Exp Ther. 2013; 346:113-120. [PubMed: 23633618]

62. Gay SC, Roberts AG, Maekawa K, Talakad JC, Hong WX, Zhang Q, Stout CD, Halpert JR. Structures of cytochrome P450 2B4 complexed with the antiplatelet drugs ticlopidine and clopidogrel. Biochemistry. 2010; 49:8709-8720. [PubMed: 20815363]

63. Denisov IG, Baas BJ, Grinkova YV, Sligar SG. Cooperativity in cytochrome P450 3A4: linkages in substrate binding, spin state, uncoupling, and product formation. J Biol Chem. 2007; 282:70667076. [PubMed: 17213193]

64. Fernando H, Halpert JR, Davydov DR. Resolution of multiple substrate binding sites in cytochrome P450 3A4: The stoichiometry of the enzyme-substrate complexes probed by FRET and Job's titration. Biochemistry. 2006; 45:4199-4209. [PubMed: 16566594]

65. Denisov IG, Grinkova YV, Baylon JL, Tajkhorshid E, Sligar SG. Mechanism of drug-drug interactions mediated by human cytochrome P450 CYP3A4 monomer. Biochemistry. 2015; 54:2227-2239. [PubMed: 25777547]

66. Davydov DR, Davydova NY, Sineva EV, Halpert JR. Interactions among cytochromes P450 in microsomal membranes: oligomierization of cytochromes P450 3A4, 3A5, and 2E1 and its functional consequences. J Biol Chem. 2015; 290:3850-3864. [PubMed: 25533469]

67. Nishio M, Umezawa Y, Fantini J, Weiss MS, Chakrabarti P. CH-pi hydrogen bonds in biological macromolecules. Phys Chem Chem Phys. 2014; 16:12648-12683. [PubMed: 24836323]

68. Dalkas GA, Teheux F, Kwasigroch JM, Rooman M. Cation- $\pi$, amino- $\pi, \pi-\pi$, and H-bond interactions stabilize antigen-antibody interfaces. Proteins. 2014; 82:1734-1746. [PubMed: 24488795]

69. Beale TM, Chudzinski MG, Sarwar MG, Taylor MS. Halogen bonding in solution: thermodynamics and applications. Chem Soc Rev. 2013; 42:1667-1680. [PubMed: 22858664]

70. Ren J, He Y, Chen W, Chen T, Wang G, Wang Z, Xu Z, Luo X, Zhu W, Jiang H, Shen J, Xu Y. Thermodynamic and structural characterization of halogen bonding in protein-ligand interactions: a case study of PDE5 and its inhibitors. J Med Chem. 2014; 57:3588-9353. [PubMed: 24702184]

71. Xu Z, Yang Z, Liu Y, Lu Y, Chen K, Zhu W. Halogen bond: its role beyond drug-target binding affinity for drug discovery and development. J Chem Inf Model. 2014; 54:69-78. [PubMed: 24372485]

\section{Abbreviations}

$\begin{array}{ll}\text { CYP } & \text { Cytochrome P450-dependent monooxygenase } \\ \text { 7-EC } & \text { 7-ethoxycoumarin } \\ \text { 7-PrC } & \text { 7-propoxy coumarin } \\ \text { 7-BuC } & \text { 7-butoxycoumarin } \\ \text { 7-EMC } & \text { 7-ethoxy-4-methylcoumarin } \\ \text { 7-PrMC } & \text { 7-propoxy-4-methylcoumarin } \\ \text { 7-BuMC } & \text { 7-butoxy-4-methylcoumarin } \\ \text { 7-EFC } & \text { 7-ethoxy-4-(trifluoromethyl) coumarin }\end{array}$




\begin{tabular}{ll} 
7-PrFC & 7-propoxy-4-(trifluoromethyl)coumarin \\
7-BuFC & 7-butoxy-4-(trifluoromethyl)coumarin \\
7-CIEFC & 7-(2-chloroethoxy)-4-(trifluoromethyl)coumarin \\
7-BrEFC & 7-(2-bromoethoxy)-4-(trifluoromethyl)coumarin \\
7-HC & 7-hydroxycoumarin \\
7-HMC & 7-hydroxy-4-methylcoumarin \\
7-HFC & 7-hydroxy-4-(trifluoromethyl)coumarin \\
RNase & ribonuclease A \\
DNase & deoxyribonuclease I \\
BME & 2-mercaptoethanol \\
PMSF & phenylmethanesulfonyl fluoride \\
CHAPS & 3-[(3-cholamidopropyl)dimethylammonio]-1-propanesulfonate \\
EDTA & ethylenediaminetetraacetic acid \\
DTT & dithiothreitol \\
7-AC & 7-alkoxycoumarin \\
7-AMC & 7-alkoxy-4-methyl coumarin \\
7-AFC & 7-alkoxy-4-(trifluoromethyl)coumarin \\
CYMAL-5 & 5-cyclohexyl-1-pentyl- $\beta$-d-maltoside \\
E. coli & Escherichia coli \\
Ni2+-NTA & Nickel-nitrilotriacetic acid affinity resin \\
FA-4 & 3a, 7a, 12a-Tris[( $\beta$-D-maltopyranosyl)ethyloxy]cholane \\
HRMS & high resolution mass spectrometry \\
DART & direct analysis in real time \\
\hline
\end{tabular}




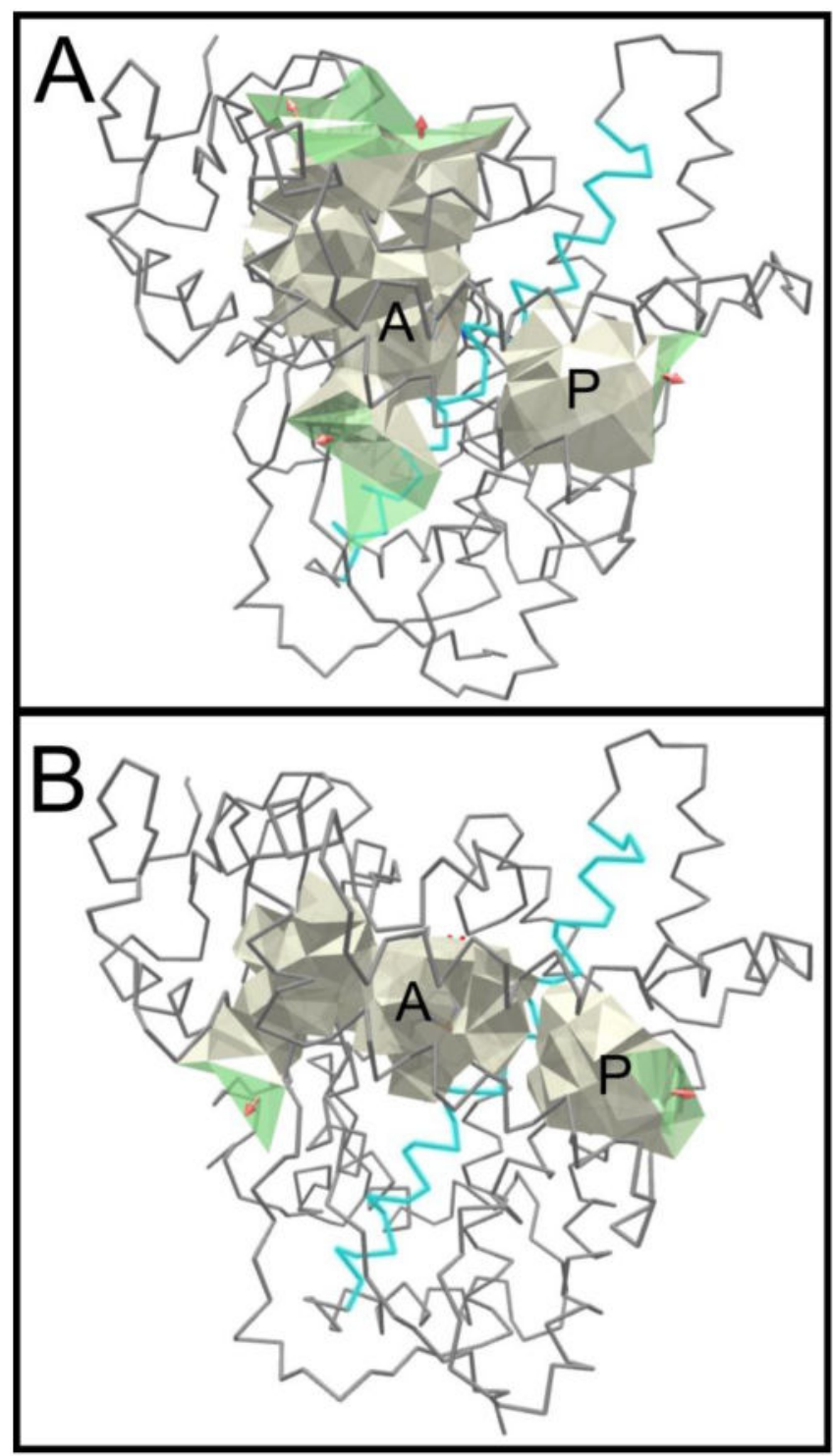

Figure 1.

Observed peripheral pocket in CYP2B enzymes. Cavities found in the A) CYP2B4paroxetine complex (4JLT) and the B) CYP2B6-(+)-a-pinene complex (4I91) using Mole 2.0 are depicted as surfaces, the protein backbone is shown as a gray ribbon, and the solvent accessible surface of the cavity is in green. In both cases, the active site, labeled A, is physically separated from the peripheral pocket, labeled P, by the I-helix (cyan). 
<smiles>[R20]Oc1ccc2c([R1])cc(=O)oc2c1</smiles><smiles>[R][CH]C</smiles>
$\mathrm{R}_{2}=\mathrm{C}_{2}-\mathrm{C}_{4}, 2-4$ carbon atoms<smiles>CCOc1ccc2c(C)cc(=O)oc2c1</smiles><smiles>[Mg]</smiles>

\section{7-EFC}

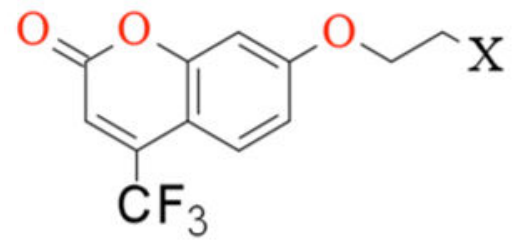

7-BrEFC $\mathrm{X}=\mathrm{Br}$ 7-ClEFC $\mathrm{X}=\mathrm{Cl}$

Figure 2.

Chemical structure of 4-substituted-7-alkoxycoumarins. 


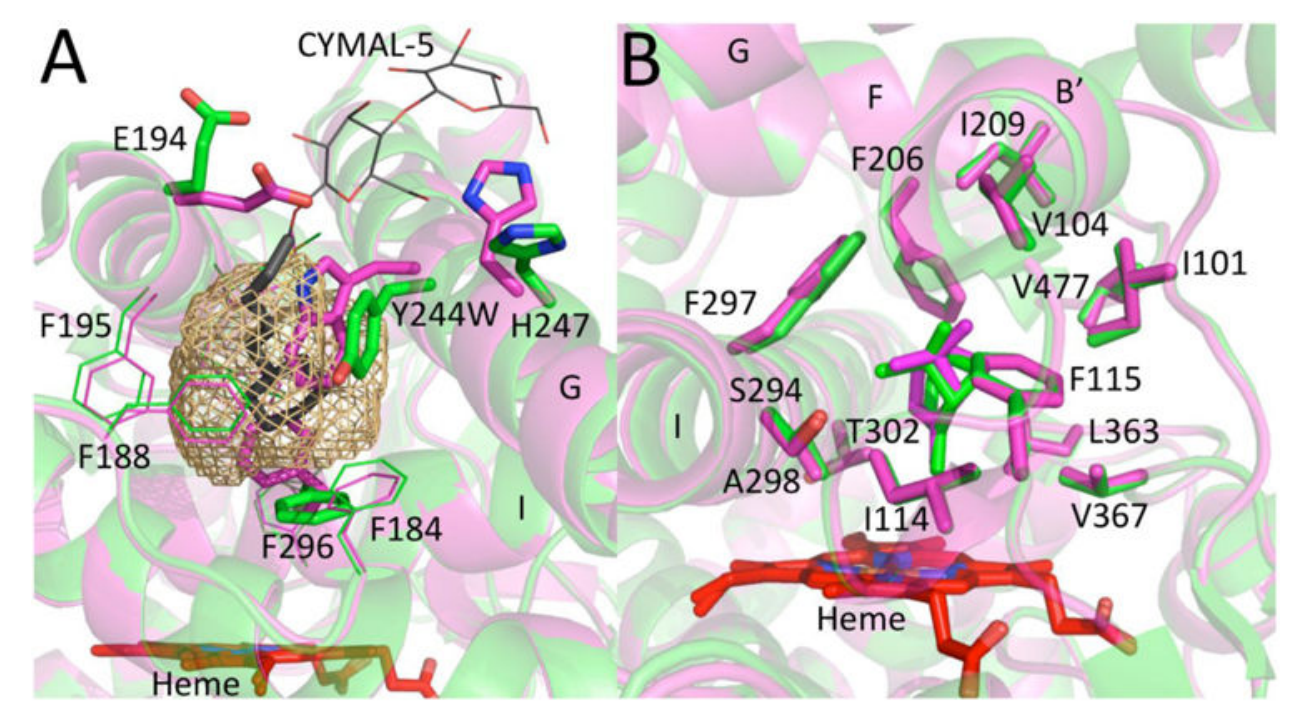

Figure 3.

Views of CYP2B6 WT and CYP2B6 Y244W complexes with (+)-a-pinene. A) Overlay of the residues in sticks lining the peripheral pocket (brown mesh) of the CYP2B6-(+)-apinene (green) complex and the CYP2B6 Y244W-(+)-a-pinene (magenta) complex. The CYMAL-5 molecule observed in CYP2B6 peripheral pocket is shown in black sticks. For visual purposes, the sugar moiety of CYMAL-5 that extends to the protein surface is shown in thin lines. The side chains of residues 194, 244, and 296 shown in sticks demonstrated significant differences in orientation in the peripheral pocket. B) Overlay of the residues in sticks lining the active-sites of CYP2B6-(+)-a-pinene (green) and CYP2B6-Y244W-(+)-apinene (magenta) within a $5 \AA$ radius of the ligand. The heme is shown in red sticks. Respective (+)-a-pinene molecules in the active site and side chain F297 on the I-helix are represented in sticks. 


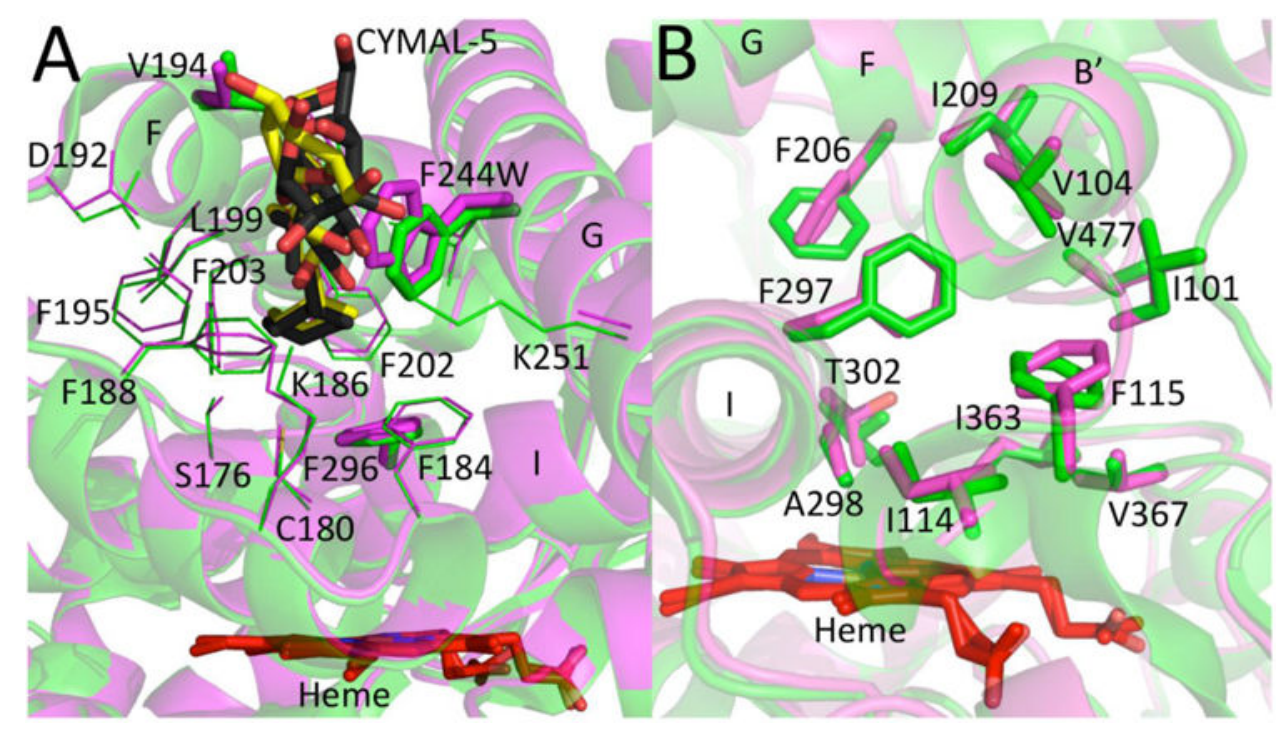

Figure 4.

Views of CYP2B4 WT and CYP2B4 F244W structures. A) Overlay of the residues lining the peripheral pockets of ligand-free CYP2B4 (green) and ligand-free CYP2B4 F244W (magenta). CYMAL-5 molecules observed in CYP2B4 and CYP2B4 F244W peripheral pocket are shown in gray and yellow sticks, respectively. The sugar moiety of CYMAL-5 is not clearly visible due to its alternate orientation towards the viewer. Residues show little or no difference in orientation between the two CYP2B4 structures in the presence of CYMAL-5 in the peripheral pocket. The side chain of residues 194, 244, and 296 that demonstrated difference in CYP2B6 complex with and without CYMAL-5 are shown in sticks. B) Overlay of the residues in sticks of the active-sites of ligand-free CYP2B4 (green) and ligand-free CYP2B4-F244W (magenta). The heme is shown in red sticks. 

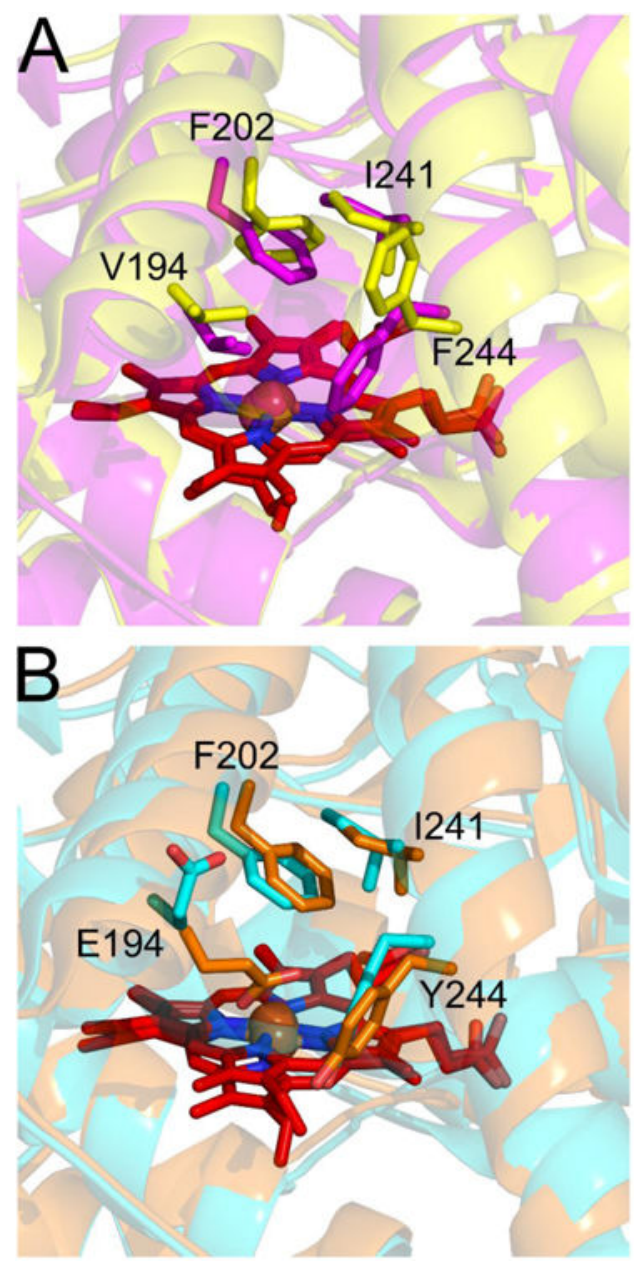

Figure 5.

Views comparing orientations of residues 194, 202, 241, and 244 in CYP2B4 and CYP2B6. A) Overlay of the CYP2B4-4-CPI complex (magenta, 1SUO) and the CYP2B4-amlodipine complex (yellow, 3TMZ). B) Overlay of the CYP2B6-4-CPI complex (cyan, 3IBD) and the CYP2B6-amlodipine complex (orange, 3UA5). Residues 194, 202, 241, and 244 are shown in sticks. The phenyl ring of F202 and $\delta$-carbon of I241 are within $4 \AA$ of each other in each structure. 


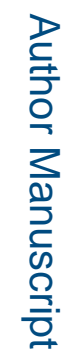

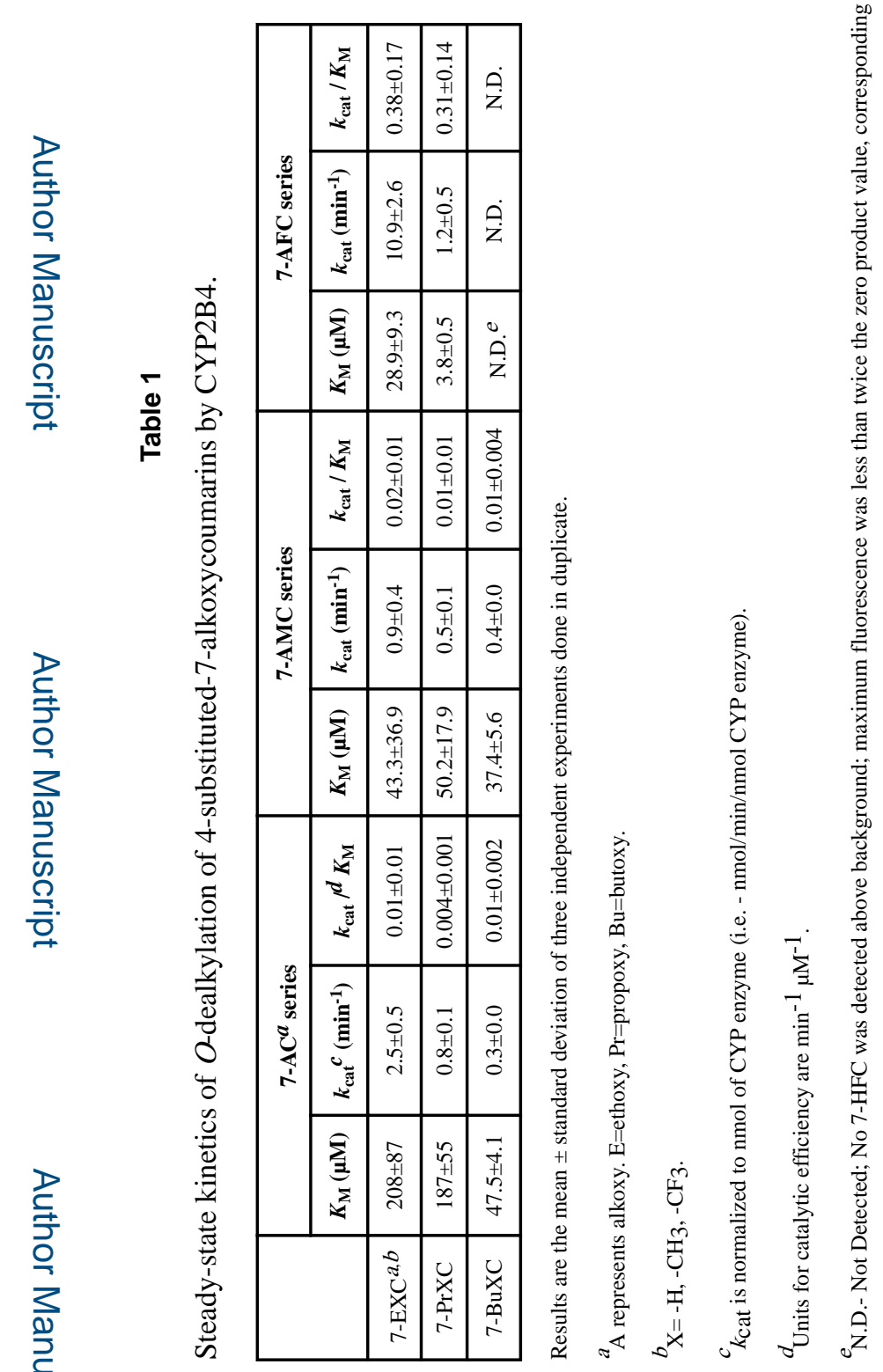




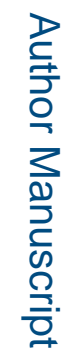

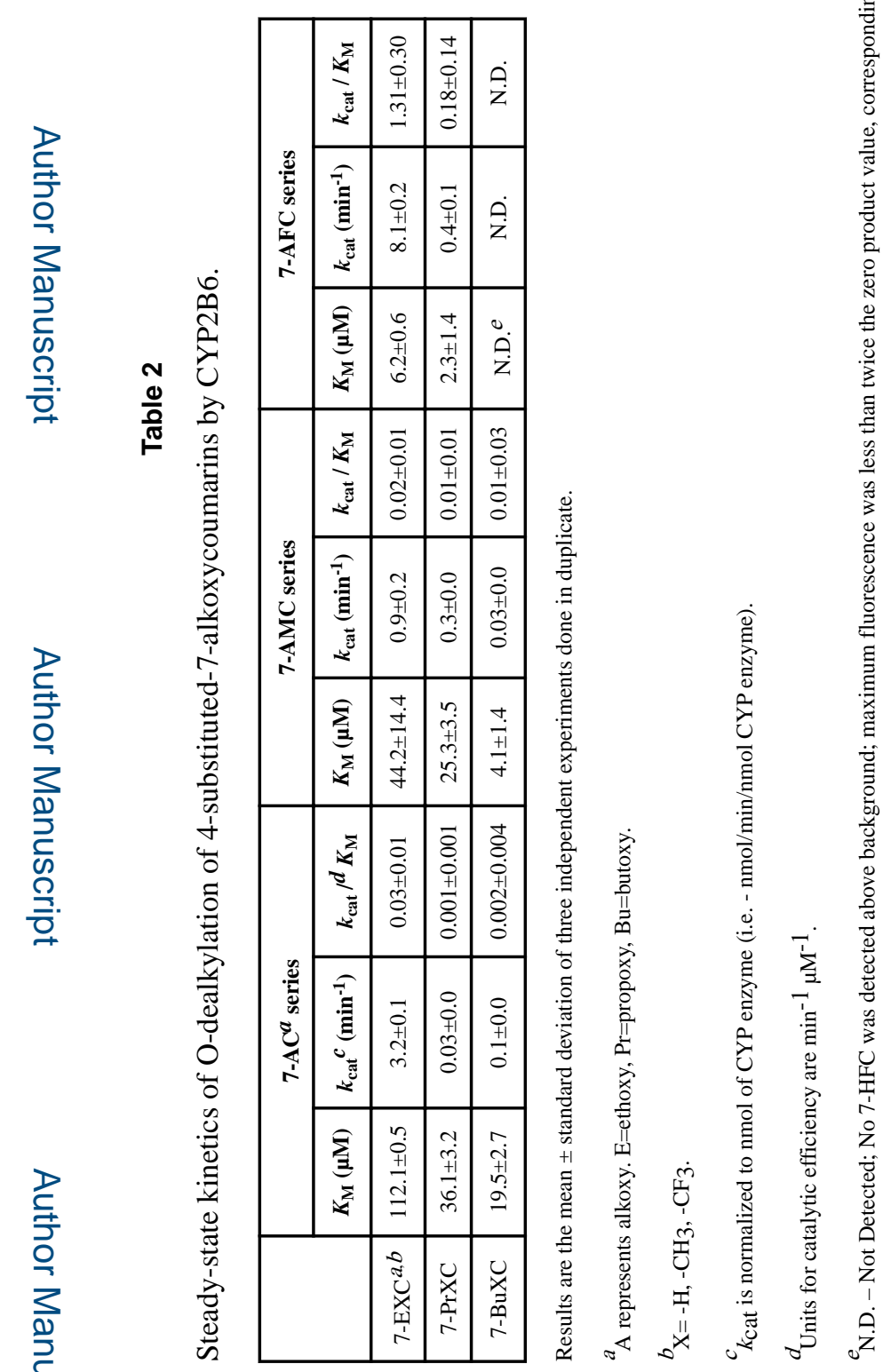




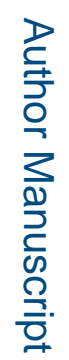

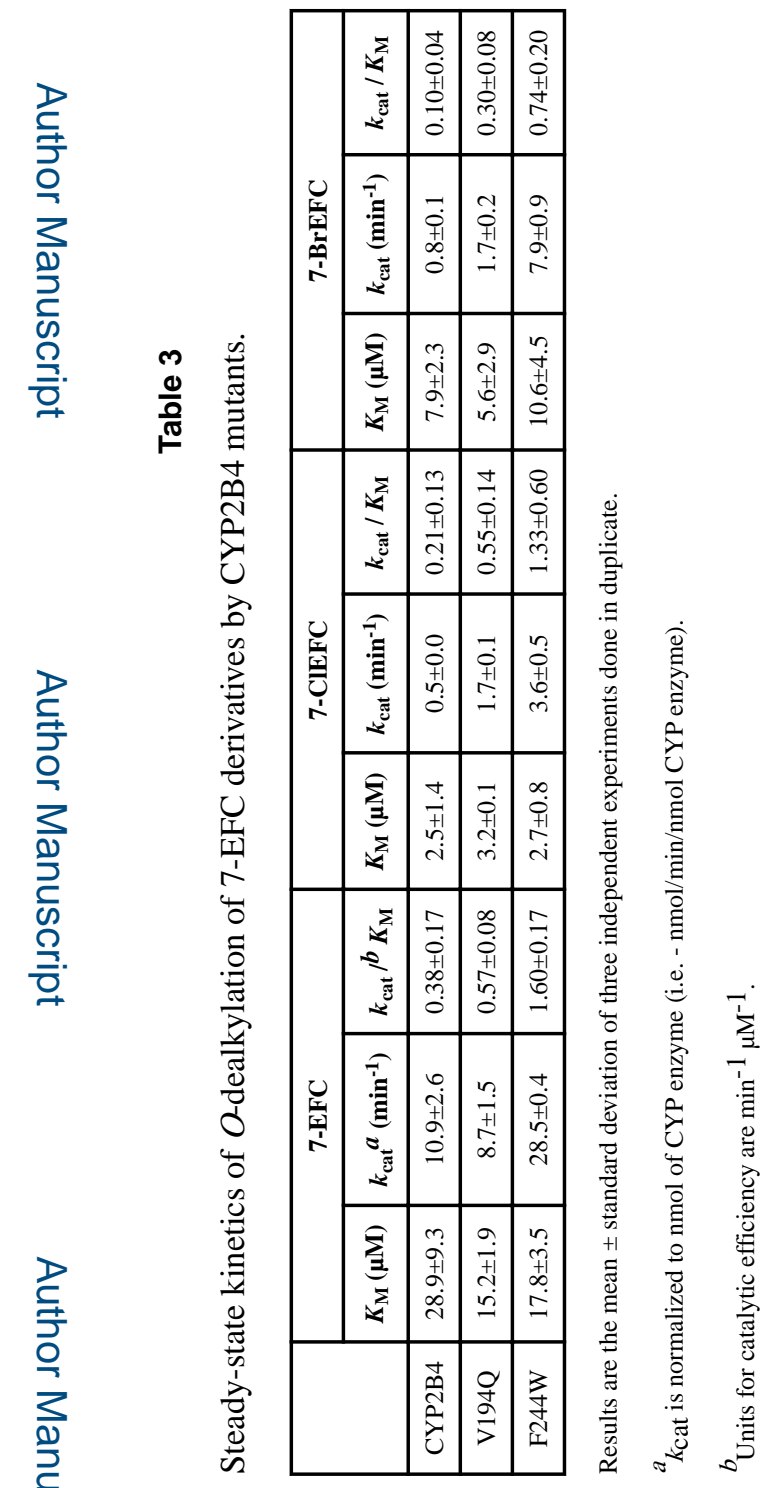




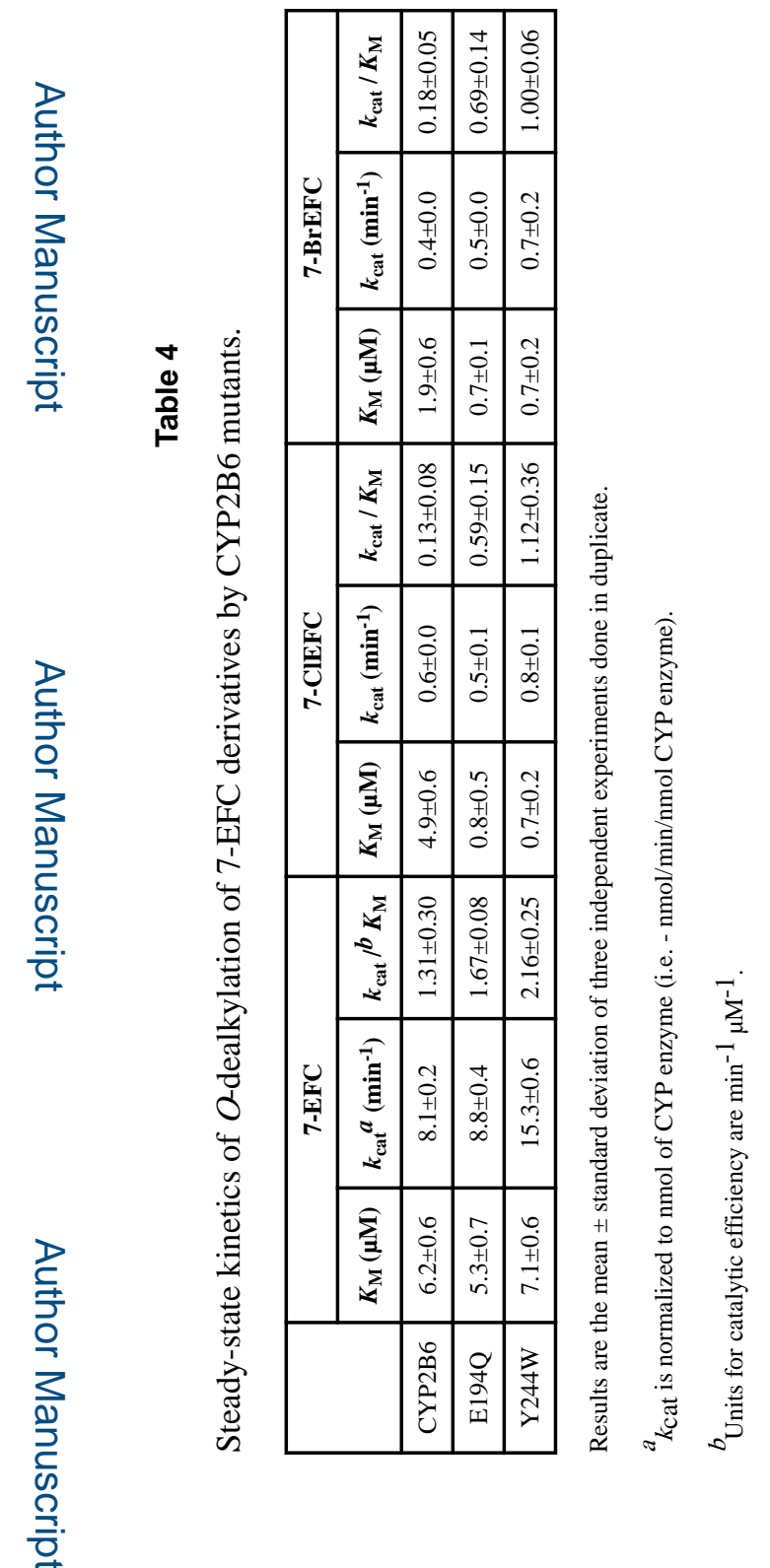

